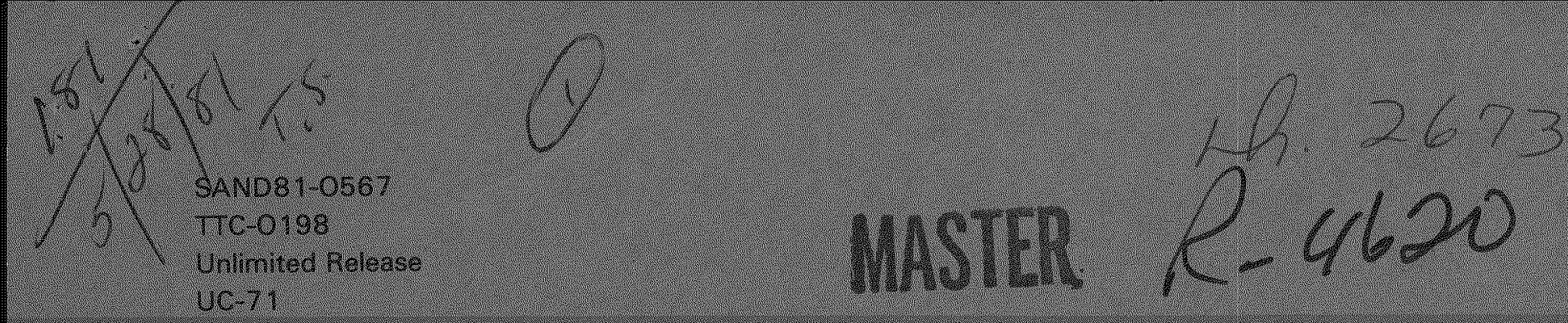

Proposed Design Requirements for HighIntegrity Containers Used to Store, Transport. and Dispose of High-Specific-Activity. LowLevel Radioactive Wastes From Three Mile Island Unit II

M. G. Vigit, G, C. Allen, R. B. Pope

Transportation Technology Conter:

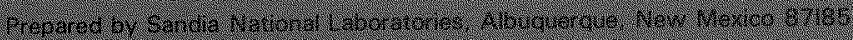

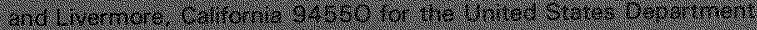

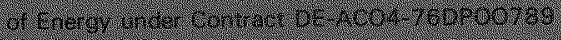

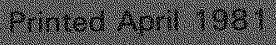


Is sued by Sandia Nationat Labonatortes, operated for the United States Department of Energy by Sandf a Corporation.

\section{NOTICE}

This revort was prepared as an account of work sponsored by the United States Govemnent. Neither the Unitad states nor the United States Department of Energy; nor any of their employees, nor any of their contractors, subcontractors or their employees, nakes any warrahty, express of imp? ied, or assumes any legallijabili ty or resoonsibility for the accuracy, cormil eteness or use ful ness of any information, apparatus, product or process disclosed, or represents that its use would not infringe privately ownerio rights.

Printed in the United States of Amertica

Aval Table from:

National Technical Information Serwice

U. S. Department of Commerce

6285. Port Royal Road

Springfte1d, VA 22167

Price: Printed Copy \$4.50: Microfiche $\$ 3.00$ 


\section{DISCLAIMER}

This report was prepared as an account of work sponsored by an agency of the United States Government. Neither the United States Government nor any agency Thereof, nor any of their employees, makes any warranty, express or implied, or assumes any legal liability or responsibility for the accuracy, completeness, or usefulness of any information, apparatus, product, or process disclosed, or represents that its use would not infringe privately owned rights. Reference herein to any specific commercial product, process, or service by trade name, trademark, manufacturer, or otherwise does not necessarily constitute or imply its endorsement, recommendation, or favoring by the United States Government or any agency thereof. The views and opinions of authors expressed herein do not necessarily state or reflect those of the United States Government or any agency thereof. 


\section{DISCLAIMER}

Portions of this document may be illegible in electronic image products. Images are produced from the best available original document. 
SAND81-0567

TTC -0198

UC-71

Unlimited Release

PROPOSED DESIGN REQUIREMENTS FOR HIGH-INTEGRITY CONTAINERS USED TO STORE, TRANSPORT, AND DISPOSE OF HIGH-SPECIFIC-ACTIVITY, LOW-LEVEL RADIOACTIVE WASTES FROM THREE MILE ISLAND UNIT II

M. G. Vigil and G. C. Allen

Transportation Systems Development and Testing Division 4553

and

R. B. Pope

Transportation Systems Technology and Analysis Division 4552

TRANSPORTATION TECHNOLOGY CENTER

Sandia National Laboratories

Albuquerque, NM 87185

April 1981

ABSTRACT

This report develops proposed design requirements for high integrity containers used to store, transport and/or dispose of high-activity, low-level, radioactive wastes from Three Mile Island Unit II. The wastes considered are the dewatered resins produced by the EPICOR II waste treatment system used to clean-up the auxiliarybuilding water. The radioactivity level of some of these EPICOR II liners is 1300 curies per container. These wastes maybe disposed of in an intermediate depth burial $(10-20$ meter depth) facility. The proposed container design requirements are directed to ensure isolation of the waste and protection of the public health and safety.

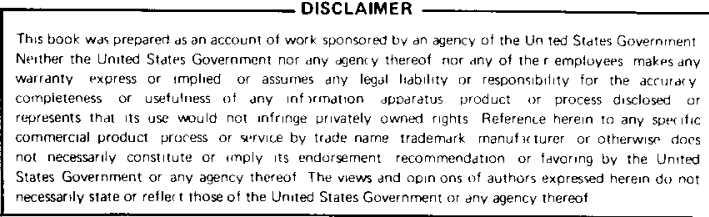


The authors gratefully acknowledge the contributions of the following people in preparing this final report:
R. E. Holzworth, EG\&G
R. L. Chapman, EG\&G
J. A. Adam, Ford, Bacon \& Davis, Utah
D. R. Buchanan, General Public Utilities
W. M. Hipsher, U. S. Ecology
K. Carlson, DOE/ALO
C. Negin, GPU/IEAL
T. C. Johnson, NRC/WM
L. Bell, NRC/TMIPO
F. Tooper, DOE/OLWR
J. Dieckhoner, DOE/HO/WM
D. Harward, Atomic Industrial Forum
K. Gablin, Private Consultant
R. E. L. Standford, EEI/UNWMC
A. A. Trujillo, Sandia National Laboratories
E. L. Wi lmot, Sandia National Laboratories 
PROPOSED DESIGN REQUIREMENTS FOR HIGH INTEGRITY CONTAINERS USED TO STORE, TRANSPORT, AND DISPOSE OF HIGH SPECIFIC-ACTIVITY, LOW LEVEL RADIOACTIVE WASTES FROM THREE MILE ISLAND UNIT II

List of Illustrations....................................... iv

List of Tables............................................

Summary ..................................................

Introduction...........................................

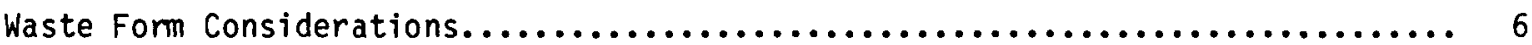

HIC Internal Environment Definition.............................. 6

Dewatered Resin Water Content.....................................

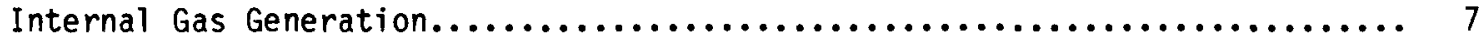

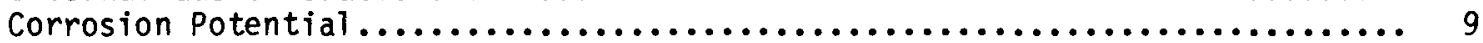

HIC External Disposal Environment Definition........................

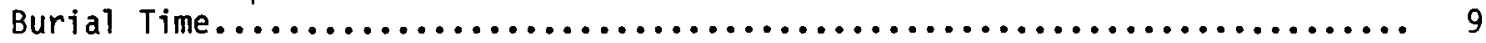

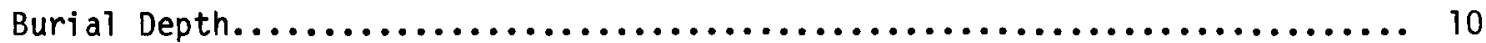

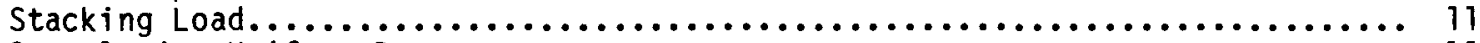

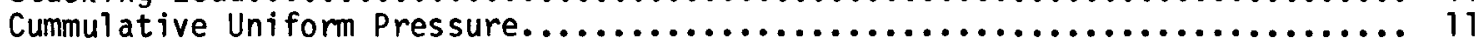

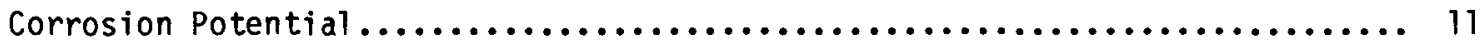

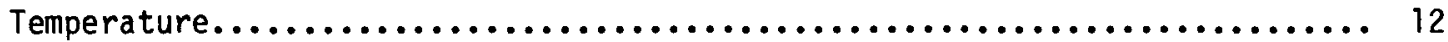

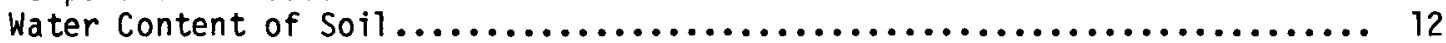

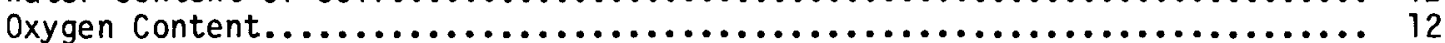

Soil Chloride Levels....................................... 12

Soit pH................................................. 13

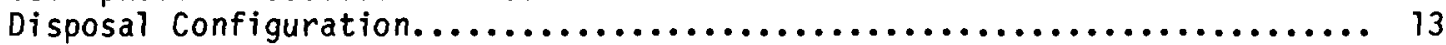

Heat Generation........................................... 13

Functional Considerations.................................... 13

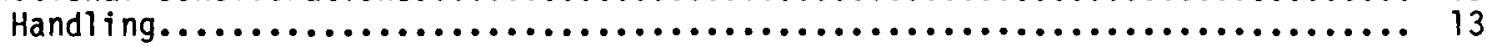

HIC Loading Configuration.................................... 14

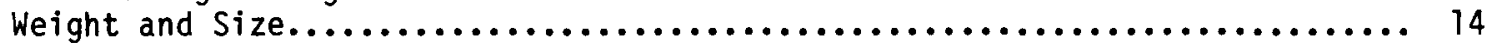

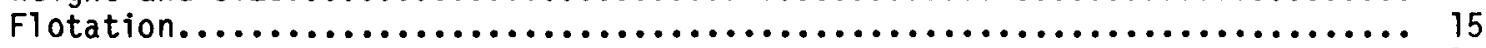

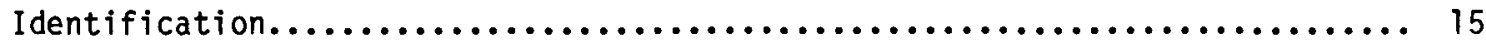

Transportation Environment Definition............................ 15

Interim Storage Environment Definition........................... 15

Summary of Proposed Design Requirements.......................... 16

References.............................................. 19

Appendix A: Previous HIC Design Guidelines

Appendix B: Terminology and Assumed Definitions 


\section{List of Illustrations}

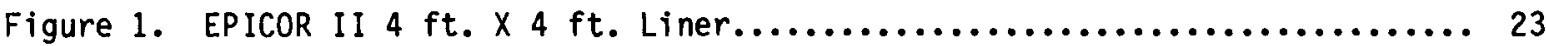

Figure 2. Absorbed Dose Versus Lifetime for a $4 \mathrm{ft}$. dia. X...................... 24

$4 \mathrm{ft}$. Long Resin Waste Container (1200 Ci, Cs137)

Figure 3. Generated Gas Yield Versus Lifetime for a $4 \mathrm{ft}$. dia. X ........... 25

$4 \mathrm{ft}$. Long Resin Waste Container (1200 Ci, Cs137)

Figure 4. Generated Radiolytic Pressure Versus Lifetime for a $\ldots \ldots \ldots \ldots \ldots \ldots 26$

$4 \mathrm{ft}$. dia. X $4 \mathrm{ft}$. Long Resin Waste Container (1200 Ci, Cs137)

Figure 5. Schematic Presentation of EPICOR II Processing System............. 27 at Three Mile Island

Figure 6. Fraction of the Original Radiotoxicity Reaching the.............. 28 Accessible Environment as a Function of Container Life

(F) and Groundwater Travel Time (GT). 
TABLE I. Reported Activity Levels of Selected Nuclides

TABLE II. Calculated Curie Deposition in PF-29 
,

, 
PROPOSED DESIGN REQUIREMENTS FOR HIGH INTEGR ITY CONTAINERS USED TO STORE, TRANSPORT, AND DISPOSE OF HIGH SPECIFIC ACTIVITY, LOW LEVEL RADIOACTIVE WASTES FROM THREE MILE ISLAND UNIT II

\section{Summary}

This report develops proposed design requirements for high integrity containers used to store, transport and/or dispose of high-activity, low-level, radioactive wastes from Three Mile Island Unit II. The wastes considered are the dewatered resins produced by the EPICOR II waste treatment system used to clean-up the auxiliary building water. The radioactivity level of some of these EPICOR II liners is 1300 curies per container. These wastes may be disposed of in an intermediate depth burial (10 - 20 meter depth) facility. The proposed container design requirements are directed to ensure isolation of the waste and protection of the public health and safety.

Requirements are developed for a high integrity container (HIC) to withstand defined internal and external environments as wel 1 as the functional operations during the $\mathrm{HIC} 1 \mathrm{ife-}$ time. The proposed design requirements derived in this report, using the criteria specispecified later are summarized below:

\section{Waste Form Characterization}

The proposed HIC design requirements are applicable to high specific activity low level (HSALL) radioactive waste from Three Mile Island Unit II requiring an intermediate depth burial (IDB) of about 15 meters (50 feet). These nuclides are primarily Cesium-137 (30.2 year half-life) and Strontium-90 (29 year half-1ife).

1. The initial isotopic content of the waste form is listed in Tables I and II.

2. The initial waste form surface (1iner) radiation source is $2000 \mathrm{R} / \mathrm{hr}$.

\section{HIC Internal Environment Requirements}

The HIC must be designed to resist the internal environment defined in the Ridihalgh, Eggers \& Associates (REA) report [4] and the following requirements are proposed:

1. The initial quantity of free liquid available in the HIC shall be less than 1 percent by volume.

2. Controlled venting of gases (Tritium, $\mathrm{H}_{2}, \mathrm{SO}_{x}, \mathrm{CH}_{4}, \mathrm{NO}_{x}, \mathrm{CO}, \mathrm{CO}_{2}$ ) shall be designed into the HIC. The HIC design shall not ailow liquids to enter or leave the container.

3. The HIC shall be designed to resist internal corrosion due to the waste form given the initial parameters below:

a. The initial waste form heat generation of 4 watts.

b. The initial gases contained in the waste form are saturated air, $\mathrm{H}_{2}$, $\mathrm{SO}_{x}, \mathrm{CH}_{4}, \mathrm{NO}_{x}$, and $\mathrm{CO}_{2}$. 
c. The chloride content of the waste form shall be considered.

d. The initial pH of the liquid in the HIC ranges between 2 and 9 .

\section{HIC Externai Environment Requirements}

The HIC must be designed to resist the external environment defined in the Ford, Bacon, \& Davis, Utah (FBDU) report [5] and the following requirements are proposed:

1. The HIC shall retain all liquids and solids for a 300 year lifetime.

2. The HIC shall be designed for a maximum burial depth of 30 meters.

3. The HIC shall be able to withstand a stacking load of $0.24 \mathrm{MPa}$ (34 PSIG).

4. The HIC shall be designed to withstand a combined uniform external pressure of $1.0 \mathrm{MPa}$ (145 PSIG).

5. The HIC shall be designed to resist external corrosion due to the disposal site environment given the initial soil parameters discussed below:
a. Ambient Soil Temperature, HIC design value: $20^{\circ} \mathrm{C} \pm 10^{\circ} \mathrm{C}$
b. Water Content of Soil, HIC design value: 0 to $100 \%$
c. Oxygen Content, HIC design value: 0 to $3 \mathrm{mg} / 1 \mathrm{iter}$
d. Chloride Content, HIC design value: 0 to 6 parts per million
e. $\mathrm{pH}$, HIC design value: 4.0 to 9.0

6. The HIC shall be designed such that water is not entrapped or retained on its external surfaces.

7. The HIC shall be designed such that the disposal configuration minimizes void spaces which would be difficult to backfill.

8. The HIC shall be capable of withstanding an internal thermal load of 4 watts in the disposal environment.

\section{HIC Functional Requirements}

1. The HIC and associated lifting devices shall withstand a 3 g vertical load.

2. The HIC lifting rings and other auxiliary lifting devices on the containers shall be recessed, offset or hinged, in a manner which does not inhibit stacking or placement inside of an existing Type B container if it is required.

3. The HIC shall be compatible with existing handling equipment at the reactor, storage, and disposal sites and if it is not a Type B package it shall be compatible with existing transportation systems.

4. The HIC shall be designed with the capability of being loaded at the reactor site. 
5. The HIC shall be capable of being transported in a legal weight truck configuration $(73,300 \mathrm{GVW})$.

6. The bulk specific gravity of the HIC and waste form shall be greater than 1.2.

7. The HIC shall have permanent markings (e.g., engraved in metal) identifying loading date, isotopes with half lives greater than 10 years, waste form and source of waste form.

HIC Transportation Requirements

1. The HIC shall meet, as a minimum, the normal transport structural requirements and design conditions for a Type A package outlined in 49CFR173.398(b) and 10CFR71 Appendix A.

2. The HIC shall be designed to the 1OCFR71 requirements if it is to be used as a Type B transportation container.

\section{HIC Interim Storage Requirements}

1. Freeze/thaw cycling for a minimum 10 year period shall be considered in the HIC design.

2. A minimum of one-year storage period as required in 10CFR71 shall be considered in the HIC design. 
This page intentionally left blank. 


\section{Introduction}

Dewatered resin wastes are frequently producd as part of the commercial nuclear fuel cycle. The Nuclear Regulatory Commission (NRC) is requiring that such wastes be solidified prior to disposal beginning in July 1981 [1]. As an alternative to solidification, it was suggested by NRC that high integrity containers (HIC) could be used [2]. Such containers could be more cost effective than solidification while providing comparable levels of protection to the public and the environment.

Liners of resin waste being produced during the clean-up of the auxilliary building water at the Three Mile Island (TMI) Unit II reactor need to be either solidified or placed in an HIC prior to disposal. These wastes, which are produced with the EPICOR II waste treatment system, include ion exchange media, filter media and other media that remove and concentrate radioactive contaminants. Many of the EPICOR II liners that have been loaded with wastes at TMI have high concentrations of radioactive materials (up to 1300 curies per liner, excluding metastable daughter products). This level of concentration is generally higher than is produced during normal reactor operations.

The activity levels of the TMI dewatered resins are higher than for wastes which are normally accepted for disposal by shallow land burial, and therefore they may require disposal in an intermediate depth burial (IDB) fasility or through some other disposal means which will provide a higher degree of confinement than that provided by shallow 1 and burial. It was proposed in August 1980 by the U. S. Department of Energy that, as an alternative to solidifying the EPICOR II wastes at TMI, an HIC could be developed that could be used not only for disposal but al so for interim storage and for transportation. The Transportation Technology Center (TTC) at Sandia National Laboratories (SNL) undertook the task of assessing the feasibility of an HIC for storing, transporting and disposing of these wastes. One incentive for developing a multi-use HIC is that an IDB facility does not currently exist and interim storage for some undefined but limited time period could be required. Once packaged in an HIC for storage, personnel exposure would be minimized if the same package could then be used for both transportation and disposal.

Design requirements for the transportation environment for such an $\mathrm{HIC}$ can be developed from the federal regulations which govern the transportation of radioactive materials. However, it was determined that waste acceptance criteria for IDB are not currently defined, and the environment produced inside an HIC by the waste form itself was not well known. Therefore, the first step in assessing the feasibility of developing an HIC for the TMI dewatered resins was to establish the internal and external environments.

The internal environment of an HIC containing EPICOR II dewatered resins was scoped by Eggers, et. a1. [4] and the environment external to an HIC during intermediate depth burial was defined by Adam and Rattigan [5]. The scope of these efforts was necessarily limited because of time constraints and limitations on available information.

An HIC must be designed to resist internal (waste form) and external (disposal site geology) corrosion, and provide structural strength to last the required period of time. The proposed HIC package design requirements for these wastes are developed here as a result of multiple inputs. The proposed HIC requirements are directed to assure isolation of the waste for a period of time long enough to permit the waste to decay to a level of activity compatible with the disposal site low level beta-gamma waste requirements. Design guidelines used to develop these requirements 
are included in Appendix A. Specifically included are (1) minutes of July 1980 DOE meeting on EPICOR II Wastes at TMI, (2) minutes of the January 15, 1981, Atomic Industrial Forum (AIF) Subcommittee meeting on Solidification-High Integrity Container Working Group, (3) South Carolina's Department of Health and Environmental Control "Staff Position on General Criteria for High Integrity Containers", and (4) High integrity Container Design Guidelines obtained from NRC representative on March 11, 1981.

In this report, the results of the environment definition studies are summarized and are used to provide a set of proposed design criteria for high integrity containers which could be used for disposing of (and possibly storing and transporting) high specific activity low level waste (HSALL) from TMI. In each of the environment definition sections which follow, the proposed criteria that will constitute the proposed desian requirements are noted. These criteria are then summarized at the end of the report. The terminology used in this report is summarized in Appendix B.

Waste Form Characterization

The HSALL wastes of concern have higher specific activities than the 1.3 $\mu \mathrm{Ci} / \mathrm{CC}$ shallow land burial limit given for Cesium-137 in 10CFR Part 61 for LLW. The TMI Epicor II liners have activities that range from 200 to $1300 \mathrm{Ci}$ per 7 iner (excluding metastable daughter products) [4]. The $4 \times 4$ liners contain about 0.85 cubic meters (30 cubic feet) of ion exchange media. Table I lists the radionuclides found in the analysis of the auxiliary building water at TMI-II (including daughter products). The radionuclides shown have half lives ranging from 2.07 years for $\mathrm{Cs}-134$ to 30 years for $\mathrm{Cs}-137$. The NRC guidelines on waste disposal are concerned with radionuclides with half-lives greater than 5 years. Therefore, the primary nuclides of concern are Cs-137 (30 years), Sr-90 (29 years), and Tritium (12.3 years).

Table II lists the isotopic content in prefilter-29 obtained from the General Public Utilities [6]. Table II also lists the radionuclide data from REA. Columns 5 and 6 of Table II compare the relative isotopic proportions from Column 5 of Table I [4] to column 4 of Table II [6]. Column 6 of Table II was obtained by dividing the number of curies for the respective nuclide $(n)$ in column 4 by the number of curies of Cesium-137 (868.49 Ci). Column 5 of Table II was obtained by dividing the number of $\mu \mathrm{Ci} / \mathrm{ml}$ for the respective nuclide $(n)$ in Column 5 of Table I by the number of $\mu \mathrm{Ci} / \mathrm{ml}$ of Cesium-137 $(35.1 \mu \mathrm{Ci} / \mathrm{ml})$. Comparison of Columns 5 and 6 of Table II shows that the calculated curie deposition in prefilter-29 is very similar to the calculated isotopic composition for the auxiliary building water samples. Therefore, substitution of the GPU data (Table II) for the data used in the REA (Table I) study would not significantly alter the proposed requirements for the internal HIC environment.

HIC Internal Environmental Definition

The waste form (Figure 1) to be placed inside the HIC was defined as the TMI-EPICOR-II waste which includes resins, steel liner, liner coatings, seals, etc. An evaluation was performed at Ridihalgh, Eggers \& Associates (REA) under contract to the SNL/TTC to define the environments imposed on the internal surface of an HIC. In the absence of well defined waste acceptance criteria sanctioned by a regulatorybody, the environment thus defined could be used to establish part of the container design criteria. REA attempted to characterize the EPICOR II dewatered media and liner including composition, physical characteristics, isotopic content, radiation spectrum, possible modes of waste form degradation and corrosion wi thin the liners [4]. Since the composition of the EPICOR II media at TMI remains proprietary information of EPICOR, Inc., REA's estimate of waste form parameter definitions is believed to be quite conservative, and 
the conclusions reached may be overly restrictive.

Dewatered Resin Water Content

CRITERION: The initial quantity of free liquid available in the HIC shall be less than 1 percent by volume.

NRC [2] will require by July 1981 that all LLW arriving at a disposal site contain less than 0.5 percent by volume of free standing liquid or 1 gallon, whichever is less. The $6 \times 6$ TMI EPICOR II liners typically contain about 1.6 gallons [7] of free standing liquid, which is well below 1 percent. The maximum percentage (1 percent) of free liquid is a reasonable and practical restriction. However, a waste acceptance requirement based on a specific quantity (1 gallon) is not appropriate since the disposal container size or volumes vary significantly. The minimum specific quantity of free liquid requirement would force waste disposal container designers and manufacturers to consider only relatively small containers.

Internal Gas Generation

CRITERION: Controlled venting of gases (Tritium, $\mathrm{H}_{2}, \mathrm{SO}_{x}, \mathrm{CH}_{4}, \mathrm{NO}_{x}$ ) shall be designed into the HIC.

Gas generation within the HIC is one of the major concerns in the design of the HIC. Gas can be generated by radiolytic attack and by microbial impact on the radioactive waste form.

The radiolytic and microbial gas generation pressures are additive. The HIC should remain sealed for its design lifetime with the exception that gas release will be allowed (reference NRC guidelines, Page A-4, Item F). Therefore, controlled venting should be required in the HIC design. 
Estimates of the gas generating effects of radiation on the ion-exchange media have been developed by Wallace, Godbee, and Kibbey [8]. Their estimates are based on published data on the radiolys is of ion exchange media (HOMEX-50)*, and assumptions concerning the probable media and water content for the EPICOR II liners at TMI. Their evaluation shows that the principal gases generated will be hydrogen $\left(\mathrm{H}_{2}\right)$, Tritium, $\mathrm{SO}_{x}, \mathrm{CH}_{4}, \mathrm{NO}$ and hydrogen sulfate $\left(\mathrm{NaHSO}_{4}\right)$. However, the $\mathrm{NaHSO}_{4}$ produced wi $7 f$ reportedly remain within the media matrix [8]. The following assumptions were made in estimating the radiolytic gas generation [8].

1. Waste container is the EPICOR II $4 \times 4$ liner shown in Figure 1.

2. The ion exchange media is similar to HOMEX-50

3. The ion exchange media consists of $40 \%$ chemically bonded water by weight

4. $G=$ number of molecules of a substance produced for every 100 ev of energy absorbed by the media. The $G$ value for $H_{2}$ was 0.1 and the $G$ value for $\mathrm{NaHSO}_{4}$ was 0.75 .

5. The void volume of a $4 \times 4$ EPICOR II Liner (Figure 1) was 0.54 cubic meters (19 cubic feet, 22.1 cubic feet, actual).

6. Total weight of ion exchange media plus water in container is $1.14 \times 10^{6}$ grams.

7. $1200 \mathrm{Ci}$ of Cesium-137 (30 year half-life) are contained in a 4 X 4 EPICOR II liner (Figure 1) (Metastable daughter products not included).

The reported relationships from Reference 8 were used to estimate the dose (D), gas yield $(Y)$, and internal pressure $(P)$, (assuming the liner is not vented) as a function of time, and the results are illustrated in Figures 2 - 4, respectively. Figure 5 shows that a peak pressure of $0.48 \mathrm{MPa}(69 \mathrm{PSIA})$ is generated within 150 years.

McFarland [9] reported the effects of gamma radiation on ion exchange media similar to that used at TMI-II. The pressure buildup in the liner was estimated to be over $0.69 \mathrm{MPa}$ (100 psig) for the anion resin and $0.138 \mathrm{MPa}(20 \mathrm{psig})$ for the cation resin. In addition to hydrogen, hydrocarbon gases al so detected in the study [9] were methane, ethane, and propane. Controlled venting of the HIC would prevent pressure build-up of these gases.

Estimates of the gas generating effects of microbial action on ion exchange media have been made by Columbo, et. al. $[10,11]$. Bacterial growth is estimated to be totally retarded by the high activity concentration levels present in the prefilter stage of the EPICOR II system (Figure 5). However, the second or third stage demineralizers (Figure 5), which have about a thousand times less radioactive material concentrations, may permit bacteria growth after 35 to 100 years with the potential generation of primarily $\mathrm{CO}_{2}$ gas [4].

An HIC internal gas pressure as high as $0.69 \mathrm{MPa}(100 \mathrm{psig})$ has been reported [9] for waste forms similar to the EPICOR II wastes. In order to achieve a controlled release of these potentially hazardous gases, it is recommended that the HIC design incorporate a metallic sponge filter or other similar filter media which allows the passage of gases $\left(\mathrm{H}_{2}\right.$, methane, propane, ethane, etc.) without allowing the passage of materials larger than 1.5 microns. The HIC must be designed such that the pressure release system does not allow liquids to enter or leave the container.

₹The HOMEX-50 may be different from the actual TMI II resins. 
Corrosion Potential

CRITERION: The HIC shall be designed to resist internal corrosion [4] due to the waste form given the initial parameters discussed below.

a. The initial maximum waste form heat generation (estimated to be 4 watts [4], source term as listed in Table I, including daughter products).

b. The initial gas content of the waste form (saturated air, $\mathrm{H}_{2}, \mathrm{SO}_{x}, \mathrm{CH}_{4}, \mathrm{NO}_{x}$ ).

c. The chloride content of the waste form.

d. The $\mathrm{pH}$ of the free liquid in contact with the interior surface of the HIC (2 to 9$)$.

The REA study [4] defined the above parameters despite the very limited data. These parameters can be used to estimate a corrosion rate occuring uniformly over the exposed surface of typical corrosion barrier. However, if the material is susceptible to corrosion pitting (mild steels, stainless steels, etc.), then the corrosion rates are not uniform and can be very localized and unpredictable. Materials not susceptible to pitting would be needed or neutralizing agents may be included in the HIC design.

\section{HIC External Disposal Environment Definition}

Ford, Bacon \& Davis, Utah (FBDU) under contract to SNL/TTC, defined the environments imposed on the external surface of an HIC during long-term IDB disposal at typical low-level waste disposal sites. In the absence of well defined waste acceptance criteria sanctioned by regulatory bodies, the environment thus defined was used to establish part of the proposed HIC design requirements reported herein. In addition, Adam [12] provided a summary of container design philosophy.

The purpose of the FBDU study [5] was to determine the parameters that would describe the disposal environment at a 15 meter depth for typical eastern and western disposal sites. The sites studied are among those which have been used for the disposal of low-level radioactive waste: an area adjacent to Savannnah River Reservation (SRR), South Carolina (SC) and West Valley (WV), N.Y. in the East; the Hanford Reservation (HR), Washington; and the Nevada Test Site (NTS) in the West.

The FBDU investigation $[5,12]$ was limited in scope and provides only limited insights into the range of parameters which may result if other sites are used. However, estimates are made of the range of the various parameters which may exist at disposal sites. The amount of information which is available on the geochemistry and microbiology at the sites and depths of interest is limited [5]. The actual environments which will be experienced by the HIC are strongly dependent on the manner in which the site is disturbed, the other types of materials which are co-disposed with the container, the type of backfill materials used, and the manner and degree to which the site is "engineered" (i.e., the use of engineered barriers such as a clay liner). The specific disposal site selected in the future could have geologic parameter values which are outside the ranges reported by FBDU.

Burial Time

CRITERION: The HIC shall retain all liquids and solids for a 300 year lifetime.

Physical integrity of the HIC for the required period of time is considered the most important requirement. The FBDU study [12] included an analys is of a liquid waste source term, similar to the high specific-activity low-level radioactive waste from TMI 
This model was based on the following parameters:

1. Burial depth is 15 meters (50 feet).

2. A sufficient range of groundwater velocities to include both arid and humid disposal sites.

3. Cesium-137 (97\%) and Strontuim-90 (3\%) as the dominate radionuclides considered (Shorter lived isotopes are not of concern because they decay rapidly. The eventual release of any of the longer lived isotopes will not be effected by containers with lives less than tens of thousands of years).

4. If the container fails at a single point in time, then its entire contents are completely available for release.

5. A range of groundwater travel times (GT) from 0 to 3 years.

6. Average retardation times.

The fraction of the original radiotoxicity reaching the accessible environment as a function of container life based on the FBDU model is shown in Figure 6 . The top curve $(G T=0)$ yields the largest fraction. The remaining four curves of Figure $6(0.1<$ GT $<3$ years) show the fraction of the original radiotoxicity reaching the accessible environment as a function of container life and groundwater travel time. Figure 6 shows that after 10 halflives ( 300 years) for $\mathrm{Cs}_{5}-137$ and $\mathrm{Sr}-90$ there is a reduction in toxicity ranging from about $1000(G T=0)$ to $100,000(G T=3)$ depending on groundwater travel time. Two hundred years of decay will reduce the levels of Cs-137 to a level acceptable for shallow land burial as shown in Figure $6(\mathrm{GT}=0)$ taken from Reference 12 .

The FBDU [12] study (Figure 4-2 of Reference 12) shows that a container life greater than 300 years reduces the toxicity of the $\mathrm{Cs}-137$ to levels considered acceptable for a shallow land burial. The study also shows that if there are only trace amounts of longer lived isotopes (i.e. C-14, Ni-59, Te-99, I-129, Cs-135 or many of the heavy metals), a container life greater than 300 years but less than tens of thousands of years will not further reduce the activity of the material released from the container.

Therefore, for the EPICOR II wastes at TMI, a 300 year lifetime for an HIC should be required. The HIC should not allow the release of radionuclides above acceptable limits for a period of 300 years.

Burial Depth

CRITERION: The HIC shall be designed for a maximum burial depth of 30 meters.

IDB is a new disposal concept for the disposal of radioactive wastes which do not require the degree of isolation that would be provided by a deep underground repository. A detailed analys is of the optimum depth for IDB has not been publi ished. Several references $[13,14]$ suggest a minimum depth of 10 meters. One reference [15] suggests the required depth to be between 10 meters and 20 meters. The results of an unpublished analys is [16] indicates that, given sufficient depth to underlying aquifers, the optimum depth for IDB could be as great as 30 meters. Time and resource restrictions for this program precluded the detailed consideration of a broad range of depths. For the purpose of this program, an IDB depth of 15 meters (50 feet) was chosen. For those environments which can be readily expressed as a function of depth, depths to 30 meters are considered $[5-12]$. 


\section{Stacking Load}

CRITERION: The HIC shall be able to withstand a stacking load of $0.24 \mathrm{MPa}$ (34 PSIG).

The HIC should have sufficient structural integrity to support the stacking of containers up to 10 meters high. The stacking pressure on top of an HIC due to a $10 \mathrm{~m}$ (33 feet) high concrete column would be $0.24 \mathrm{MPa}$ (34 PSIG).

\section{Cumulative Pressure}

CRITERION: The HIC shall be designed to withstand a combined uniform external, pressure of $1.0 \mathrm{MPa}$ (145 PSIG).

A buried container must be able to support the placement of additional waste and overburden for a 30 meter (100 feet) burial depth. The overburden densities could vary between $1.6 \mathrm{gm} / \mathrm{cc}\left(100 \mathrm{lb} / \mathrm{ft}^{3}\right)$ for sand to $2.4 \mathrm{gm} / \mathrm{cc}\left(150 \mathrm{lb} / \mathrm{ft}^{3}\right)$ for concrete. A maximum of ten meters (33 feet) of waste with a density equivalent to concrete would be expected to be included in the overburden. The effective lithostatic pressure on a buried container is dependent on the amount of compaction of the backfill and the water content of the soil. Any hydrostatic pressure would be additive with the effective lithostatic pressure. The hydrostatic pressure depends on the depth below the water table. If it is assumed that the IDB is above the water table, as it would be for the dry or western sites, the hydrostatic pressure would be nearly zero. Reference 5 shows a hydrostatic pressure for a wet site of $0.29 \mathrm{MPa}$ (43 PSIG) at a $30 \mathrm{~m}$ (98 feet) depth for the water table at a depth of $1.52 \mathrm{~m}(5 \mathrm{feet})$. The total or cumulative pressure is the sum of the effective lithostatic and hydrostatic pressures at a $30 \mathrm{~m}$ depth. The pressures are summarized below.

\begin{tabular}{|c|c|c|c|}
\hline Pressure & $\begin{array}{l}\text { Dry } \\
\text { Site } \\
\text { (MPa) } \\
\end{array}$ & $\begin{array}{l}\text { Wet } \\
\text { Site } \\
\text { (MPa) } \\
\end{array}$ & $\begin{array}{l}\text { Worst Case } \\
\quad(\mathrm{MPa}) \\
\end{array}$ \\
\hline $\begin{array}{l}\text { Soil Overburden Contribution } \\
\text { to Lithostatic*}\end{array}$ & 0.47 & 0.42 & 0.47 \\
\hline $\begin{array}{l}\text { Buried Waste Overburden } \\
\text { Contribution to Lithostatic }\end{array}$ & 0.24 & 0.24 & 0.24 \\
\hline Hydrostatic & 0 & 0.29 & 0.29 \\
\hline
\end{tabular}

FCorresponds to $30 \mathrm{~m}$ depth minus the $10 \mathrm{~m}$ of buried waste overburden.

\section{Corrosion Potential}

CRITERION: The HIC shall be designed to resist external corrosion due to the disposal site environment given the initial soil parameters discussed below, and the HIC shall be designed such that water is not entrapped or retained on its external surfaces.
a. Ambient Soil temperature, the HIC design value shall be $20^{\circ} \mathrm{C} \pm 10^{\circ} \mathrm{C}$,
b. Water Content of Soil, the HIC design value shall be 0 to $100 \%$,
c. Oxygen Content of Soil, The HIC design value shall be 0 to $3 \mathrm{mg} / 1 \mathrm{iter}$, 
d. Chloride Content of Soil, The HIC design value shall be 0 to 6 parts per million, and

e. $\mathrm{pH}$ of soil, The HIC design value shall be 4 to 9 .

The external HIC environment (disposal site) for a 15 meter (50 foot) IBD at a wet or dry site has been defined in the FBDU study $[5,12]$. The external surface of the HIC must be designed to resist the corrosion environment defined in the FBDU report. This study reports IDB humid and arid disposal site parameter ranges for soil temperature, oxygen content, chloride content, soil $\mathrm{pH}$, and water content, soil mineral composition, and microbial activity. The parameters which affect external corrosion are bounded in the following paragraphs.

\section{Temperature}

At a depth of 15 meters there is no appreciable seasonal fluctuation in temperature. The actual temperature will vary somewhat from location to location depending on the materials above and below the site and their moisture and radioactive isotope contents (principally thoriums and uraniums). A typical temperature at 15 meters is $20^{\circ} \mathrm{C}$ [5]. Temperatures will increase approximately $0.017^{\circ} \mathrm{C}$ for each meter increase in depth at typical eastern sites. The rate of temperature increase for western sites is approximately $0.027^{\circ} \mathrm{C} / \mathrm{m}[5]$. The soil temperature could increase by as much as $10^{\circ} \mathrm{C}$ near a buried HIC [5] as a result of internal heat generation.

\section{Water Content of Soil}

At both typical eastern and western sites, a wetting cycle is not experienced at a depth of 15 meters [5]. A near steady-state condition prevails in each instance. For the eastern sites, this steady-state condition is the result of saturated or near saturated conditions at 15 meters. For the western sites, this steady-state condition is dry soil since the precipitation (rain) only percolates (penetrates) a few meters before its downward movement is reversed and it evaporates at the surface.

\section{Oxygen Content}

As water from rain and snow enters the subsurface flow system, its dissolved oxygen content is initially high $(7$ to $15 \mathrm{mg} / 1)$ owing to its exposure to atmospheric oxygen [5]. In the organic-rich layers of the surface soils, the oxidation of organic matter commonly removes most of the dissolved oxygen. It is reasonable to expect that the consumption of oxygen in the soil zone will vary depending on numerous factors, including soil structure, porosity, permeability, nature and depth distribution of organic matter, temperature etc.

The relatively great depths to groundwater at the western sites results in a long contact time between infiltrating water and the porous media, allowing greater opportunity for oxygen depletion by oxidation. However, the generally low organic matter contents in western soils would tend to somewhat offset the influence of depth to groundwater. Thus, dissolved oxygen concentrations of 2 to $3 \mathrm{mg} / 1$ might be encountered.

At the eastern sites, where soil organic matter contents are relatively high and soil stratification results in low vertical permeability, dissolved oxygen contents are likely low. It is doubtful that detectable dissolved oxygen would be found in groundwater under natural conditions. Only gamma radiolysis should be considered as a potential source of oxygen. 
Soil Chloride Levels

Information on chloride levels at the depths of interest was not found. Analysis of of Savannah River Reservation surface water resulted in chloride levels ranging from 0.8 to $5.1 \mathrm{ppm}[5]$. Since ion-exchange for anions is $10 \mathrm{w}$, it is reasonable to assume that these anions are free to move with the surface waters to greater depths. Likewise, trace quantities to very low percentages of chloride are found at Hanford Reservation. The corrosive effects of chloride at the western sites may be limitd by the low moisture content of the soils.

Soil pH

A particularly misleading factor may be $\mathrm{pH}$ [5]. The methods used to determine soil $\mathrm{pH}$ (soil paste or soil suspension) do not represent actual soil conditions. The $\mathrm{pH}$ of in situ soil may be considerably different from the $\mathrm{pH}$ of a paste or suspension sample made from that soil. In situ soils may show abrupt changes in pH within inches. Studies show that the $\mathrm{pH}$ near a colloid may be up to one $\mathrm{pH}$ unit lower than the $\mathrm{pH}$ of a bulk soil solution [5]. The consideration of $\mathrm{pH}$ is further complicated by the small amount of free moisture to promote ion exchange at the western sites. The $\mathrm{pH}$ referred to in this report is that of the sample and may not be indicative, or even close to, the true in situ $\mathrm{pH}$.

Because of the saturated or partially saturated conditions at the eastern sites, the measurements and effects of $\mathrm{pH}$ have a greater significance than for the western sites. Still, pH measurements at the eastern sites may also be misleading because of the large spatial variability of $\mathrm{pH}$. The range of $\mathrm{pH}$ measured at SRR is from 4.0 [8] to $8.0[5]$.

The $\mathrm{pH}$ of the soils at the western sites falls in the range between 8.0 and 9.0 [5]. These $\mathrm{pH}^{\prime} \mathrm{s}$ do not represent in situ properties and the meaning of $\mathrm{pH}$ in the absence of free moisture is questionable.

\title{
Disposal Configuration
}

CRITERION: The HIC shall be designed such that the disposal configuration minimizes void spaces which would be difficult to backfill.

Void spaces should be minimized in a waste disposal site in order to limit the amount of soil subsidence that would occur following trench closure.

\section{Heat Generation}

CRITERION: The HIC in the disposal environment shall be capable of withstanding an internal heat generation rate of 4 watts.

Eggers, et. a1. [4] and Adam, et. al. [5,12] have shown that there is only a small internal heat generation rate. Based on bounding assumptions in Reference 4, the maximum temperature difference across the ion-exchange media was estimated to be $11^{\circ} \mathrm{C}$ to $44^{\circ} \mathrm{C}$ for a total thermal inventory of 1.0 to 4.0 watts, respectively.

\author{
Functional Considerations
}

Handling load.

CRITERION: The HIC and associated lifting devices shall withstand a $3 \mathrm{~g}$ vertical 
CRITERION: The HIC lifting rings and other auxiliary lifting devices on the container shall be recessed, offset, or hinged in a manner which does not inhibit stacking or placement inside of an existing type B container if required.

CRITERION: The HIC shall be compatible with existing handling equipment at reactor, storage and disposal sites. If the HIC is not a Type B package, it shall be compatible with existing Type B transportation systems.

The HIC and associated lifting devices should be designed to withstand loading force applied in the lifting or handling operations during its lifetime. NRC guidelines have suggested that as a minimum, the container should be able to withstand a $3 \mathrm{~g}$ vertical load.

The HIC should be designed for safe, efficient, and equipment compatible handling during storage, transportation, and disposal. The HIC should be provided with cleats, offsets, or skids that allow handling by means (forks, trucks, cranes, etc.) compatible with the storage and disposal sites. Lifting rings and other auxiliary lifting devices on the containers should be recessed, offset, or hinged, in a manner which does not inhibit stacking of the containers. The HIC should also be capable of being transported.

The HIC should be shielded to reduce the external surface dose rates to those rates acceptable in storing, transporting and disposing of the wastes. As a minimum the HIC (combined with a Type B shipping container, if the HIC does not meet Type B package criteria by itself) shall meet the following radiation dose limits (based on 49CFR173.393 and 173.398):

1. dose rate limit of 200 millirem per hour at any point on the external surface of the transportation package

2. dose rate limit of 10 millirem per hour at any point 2 meters from the vertical planes projected from the outer edges of an exclusive use vehicle.

The initial waste form (EPICOR II liner) surface radiation source is $2000 \mathrm{R} / \mathrm{hr}$.

\section{HIC Loading Configuration}

CRITERION: The HIC shall be designed with the capability of being loaded at the reactor site.

The structural design of the HIC depends on whether the HIC will be used as a storage, and/or transportation container as well as a disposal container. The HIC could be used for all three of the above functions. The disposal HIC should be installed before arriving at the disposal site. This eliminates the possibility of a spill and, therefore contaminating the disposal site.

\section{Weight and Size}

CRITERION: The HIC shall be capable of being transported by a legal weight truck configuration $(73,300 \mathrm{GWW})$.

Total HIC size and weight should be limited to be compatible with the weight limitations at the storage or disposal sites. However, the controlling size and weight limitations are expected to be transportation related. Because not all disposal sites have rail access, the HIC shall be capable of being transported by legal weight truck. 


\section{Flotation}

CRITERION: The bulk specific gravity of the HIC and waste form shall be greater than 1.2 .

The density of the HIC should be such that the loaded container does not float.

\section{Identification}

CRITERION: The HIC shall have permanent markings (e.g., engraved in metal) identifying the loading date, isotopes with half lives greater than 10 years, waste form and source of waste form.

In order to be able to identify the waste form during its required 300 year life, permanent markings are required.

\section{Transportation Environment Definition}

CRITERION: The HIC shall meet as a minimum the normal transport design requi rements and design conditions for a Type A package outlined in 49CFR173.398(b) and 10CFR71 Appendix $A[17]$.

Since the HIC must be handled, the HIC (if not a Type B container) shall meet as a minimum, the normal transport design requirements and design conditions for a Type $A$ package outl ined in 49CFR 173.398(b) and 10CFR71 Appendix A. These requirements include tests in heat, cold, pressure, vibration, water spray, free drop, penetration, and compression environments.

CRITERION: The HIC shall meet the requirements of 10CFR71 for a Type B package if it is to be designed as a Type B transportation container.

The HIC will contain Type B quantities of radioactive material and must meet these criteria if the HIC is not to be transported in a separate Type B shipping container.

\section{Interim Storage Environment Definition}

CRITERION: Freeze/Thaw cycling for a minimum 10 year period shall be considered in the HIC design.

CRITERION: A minimum of one year storage period as required in 10CFR71 shall be considered in the HIC design.

The HIC requirements for disposal and transportation are expected to be more stringent than those required for the interim storage. Freeze/thaw data for the TMI area were not currently available. These data should be obtained and incorporated into the design specifications for the HIC. 
Summary of Proposed Design Requirements

The proposed design requirements derived in this report, using the criteria specified are summarized below:

\section{Waste Form Characterization}

The proposed HIC design requirements are applicable to high specific activity low level (HSALL) radioactive waste from Three Mile Island Unit II requiring an intermediate depth burial (IDB) of about 15 meters ( 50 feet). These nuclides are primarily Cesium-137 (30.2 year half-1ife) and Strontium-90 (29 year half-life).

1. The initial isotopic content of the waste form is listed in Tables I and II.

2. The initial waste form surface (liner) radiation source is $2000 \mathrm{R} / \mathrm{hr}$.

HIC Internal Environment Requirements

The HIC must be designed to resist the internal environment defined in the Ridihalgh, Eggers \& Associates (REA) report [4] and the following requirements are proposed:

1. The initial quantity of free liquid available in the HIC shall be less than 1 percent by volume.

2. Controlled venting of gases (Tritium, $\mathrm{H}_{2}, \mathrm{SO}_{x}, \mathrm{CH}_{4}, \mathrm{NO}_{x}, \mathrm{CO}, \mathrm{CO}_{2}$ ) shall be designed into the HIC. The HIC design shall not allow liquids to enter or leave the container.

3. The HIC shall be designed to resist internal corrosion due to the waste form given the initial parameters below:

a. The initial waste form heat generation of 4 watts.

b. The initial gases contained in the waste form are saturated air, $\mathrm{H}_{2}$, $\mathrm{SO}_{X}, \mathrm{CH}_{4}, \mathrm{NO}_{X}$, and $\mathrm{CO}_{2}$.

c. The chloride content of the waste form shall be considered.

d. The initial $\mathrm{pH}$ of the liquid in the HIC ranges between 2 and 9. 


\section{HIC External Environment Requirements}

The HIC must be designed to resist the external environment defined in the ford, Bacon, \& Davis, Utah (FBDU) report [5] and the following requirements are proposed:

1. The HIC shall retain all liquids and solids for a 300 year lifetime.

2. The HIC shall be designed for a maximum burial depth of 30 meters.

3. The HIC shall be able to withstand a stacking load of $0.24 \mathrm{MPa}$ ( 34 PSIG).

4. The HIC shall be designed to withstand a combined uniform external pressure of $1.0 \mathrm{MPa}$ (145 PSIG).

5. The HIC shall be designed to resist external corrosion due to the disposal site environment given the initial soil parameters discussed below:

a. Ambient Soil Temperature, HIC design value: $20^{\circ} \mathrm{C} \pm 10^{\circ} \mathrm{C}$

b. Water Content of Soil, HIC design value: 0 to $100 \%$

c. Oxygen Content, HIC design value: 0 to $3 \mathrm{mg} / \mathrm{liter}$

d. Chloride Content, HIC design value: 0 to 6 parts per million

e. $\mathrm{pH}$, HIC design value: 4.0 to 9.0

6. The HIC shall be designed such that water is not entrapped or retained on its external surfaces.

7. The HIC shall be designed such that the disposal configuration minimizes void spaces which would be difficult to backfill.

8. The HIC shall be capable of withstanding an internal thermal load of 4 watts in the disposal environment.

\section{HIC Functional Requirements}

1. The HIC and associated lifting devices shall withstand a 3 g vertical load.

2. The HIC lifting rings and other auxiliary lifting devices on the containers shall be recessed, of fset or hinged, in a manner which does not inhibit stacking or placement inside of an existing Type B container if it is required.

3. The HIC shall be compatible with existing handling equipment at the reactor, storage, and disposal sites and if it is not a Type B package it shall be compatible with existing transportation systems.

4. The HIC shall be designed with the capability of being loaded at the reactor site. 
5. The HIC shall be capable of being transported in a legal weight truck configuration $(73,300 \mathrm{GVW})$.

6. The bulk specific gravity of the HIC and waste form shall be greater than 1.2.

7. The HIC shall have permanent markings (e.g., engraved in metal) identifying loading date, isotopes with half lives greater than 10 years, waste form and source of waste form.

\section{HIC Transportation Requirements}

1. The HIC shall meet, as a minimum, the normal transport structural requi rements and design conditions for a Type A package outlined in 49CFR173.398(b) and 10CFR71 Appendix A.

2. The HIC shall be designed to the 10CFR71 requirements if it is to be used as a Type B transportation container.

\section{HIC Interim Storage Requirements}

1. Freeze/thaw cycling for a minimum 10 year period shall be considered in the HIC design.

2. A minimum of one-year storage period as required in 10CFR71 shall be considered in the HIC design. 
References

1. Memo, S. Meyers (DOE/NE) to H. E. Roser (DOE/AL), dated June 10, 1980, Subject: Feasibility Studies of Containers for Use in Transportation and Storage/Disposal of Radioactive Waste.

2. Letter, D. G. Ei senhut (NRC) to All Power Reactor Licensees, dated January 29, 1980, Subject: Low Level Radioactive Waste Disposal.

3. Preliminary Draft, 10 CFR Part 61 : Disposal of Low-Level Radioactive Waste and LowActivity Bulk SolidWaste, November 5, 1979.

4. P. E. Eggrs, E. C. Lusk, J. R. Myers, and J. L. Ridihalgh, Definition of Waste Forms Produced by TMI Auxiliary Building Water Cleanup with the EPICOR II System, Report Number 1065/81/06 (TTC-0188), Ridihalgh, Eggers \& Associates, ATbuquerque, NM, April 1981.

5. J. Adam and L. Rattigan, Definition of Typical Intermediate Depth Burial Environment for Developing Package Design Criteria, Ford, Bacon \& Davis, Utah, Inc., Report Number FBDU 382-001 (TTC-0167), January, 1981.

6. Letter report, G. K. Hovey, Metropolitan Edisen Co., dated December 15, 1980, L. Barrett, TMI Program Office, Subject: "Methodology and Calculation of Integrated Dose to EPICOR-II Prefilters".

7. R. J. McGoey, Three Mile Isl and Unit II Resin Liner Dewatering Study, Metropol itan Edisen Company, November 28, 1919.

8. R.M. Wallace, H.W. Godbee, and A. H. Kibbey, An estimate of the Effect of Radiation on Spent Ion-Exchange II Radwaste System, (Draft Report) Savannah River Laboratory, Aiken, SC and Oak Ridge National Laboratories, Oak Ridge, TN, October 24, 1980.

9. R. C. McFarland, The Effects of Gamma Radiation on Ion Exchange Resins and Activated Charcoal, Neely Nuclear Research Center, Georgia Institute of Technology, Atlanta, Georgía, February 1980).

10. Letter, P. Columbo (Brookhaven National Laboratory) to M. G. Vigil (Sandia National Laboratory), dated November 3, 1980, Subject: "Gas Generation from Microbial Activity in Ion Exchange Resins".

11. P. Columbo, et. al., Experimental Studies Relevant to Microbial Activities in Shallow-Land Radioactive Waste Disposal Sites, BN-NUREG-51743 1980, Brookhaven National Laboratory, Upton, NY.

12. Letter report, J. A. Adam (Ford, Bacon \& Davis, Utah, Inc.), for Sandia National Laboratories, dated January 1981, Subject: "Container Design Considerations."

13. J. A. Adam and V.C. Rogers, A Classification System for Radioactive Waste Disposal - What Waste goes Where? NUREG-0456, U. S. Nuclear Regulatory Commission, Washington, DC, June 1978.

14. License for the Hanford Commercial Low-Level Radioactive Waste Disposal Facility, $W N-1019-2$, Amendment 11, Issued by the State of Washington, November 1980.

15. "State of the Art Review of Alternatives to Shallow Land Burial of Low Level Radioactive Waste," ORNL/SUB-79/13837/1, prepared by Gilbert/Commonwealth for Oak Ridge National Laboratory, Oak Ridge, Tennessee, 1979. 
16. D. Card, P. Hunter, and J. Adam, Criteria for Intermediate Depth Burial for Greater Confinement of Low Level Radioactive Wastes at Arid Western Sites, Ford, Bacon \& Davis, Utah, to be published.

17. 1OCFR Part 71: Packaging of Radioactive Material for Transportation and Transportation of Radioactive Material Under Certain Conditions; Compatibility with IAEA Regulations, U.S. NuClear Regulatory Commission, Washington, OC, August 17, 1979.

18. 49CFR Part 100 to 177: Transportation Part 173.398(b) Standards for Type A Packaging, Page 472, Code of Federal Regulations, Department of Transportation, October 1, 1979. 
TABLE I. REPORTED ACTIVITY LEVELS OF SELECTED NUCLIDES (includes daughter products)

\begin{tabular}{|c|c|c|c|c|}
\hline Nuclide & Half-Life & $\begin{array}{c}\text { 'B' }(A) \text { ISOTOPIC } \\
\text { Sample } \\
\text { ORNL Reported } \\
\text { Activity }(\mu \mathrm{Ci} / \mathrm{ml})\end{array}$ & $\begin{array}{c}\text { NVENTORY AS OF MAY } \\
\text { SampTe } 2 \\
\text { EXXON }(\mathrm{C}) \\
\text { Nuclear }(\mu \mathrm{Ci} / \mathrm{ml})\end{array}$ & 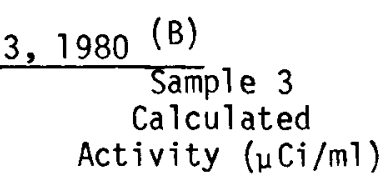 \\
\hline 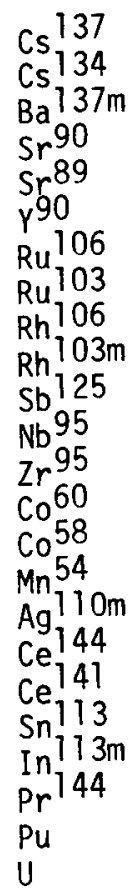 & $\begin{array}{c}30.2 \text { yrs. } \\
2.06 \text { yrs. } \\
2.55 \text { min. } \\
29 \text { yrs. } \\
50.5 \text { days } \\
64 \text { hrs } \\
368 \text { days } \\
39.4 \text { days } \\
2.18 \text { hrs } \\
56 \text { min. } \\
2.73 \text { yrs } \\
3.5 \text { days } \\
64 \text { days } \\
5.27 \text { yrs } \\
70.8 \text { days } \\
312.5 \text { days } \\
24.3 \text { sec. } \\
284.4 \text { days } \\
32.5 \text { days } \\
115 \text { days } \\
1.658 \text { hrs. } \\
17.28 \text { min. } \\
\text { - } \\
\text { - }\end{array}$ & $\begin{array}{c}37.57 \\
6.80 \\
- \\
.30 \\
.17 \\
- \\
- \\
- \\
- \\
- \\
- \\
- \\
- \\
- \\
- \\
- \\
- \\
- \\
- \\
- \\
- \\
- \\
0.12 \mathrm{ppb} \\
13.0 \mathrm{ppb}\end{array}$ & $\begin{array}{c}36.47 \\
6.75 \\
- \\
- \\
- \\
- \\
- \\
- \\
- \\
- \\
- \\
- \\
- \\
- \\
- \\
- \\
- \\
- \\
- \\
- \\
- \\
- \\
- \\
-\end{array}$ & $\begin{array}{c}35.1 \\
6.60 \\
33.34 \\
.4 \\
0.17 \\
.4 \\
1.58(-3) \\
6.83(-5) \\
1.58(-3) \\
6.83(-5) \\
5.10(-3) \\
2.90(-3) \\
1.46(-3) \\
1.31(-4) \\
5.66(-5) \\
3.19(-4) \\
4.14(-5) \\
3.48(-3) \\
9.78(-6) \\
4.11(-5) \\
4.11(-5) \\
3.48(-3) \\
- \\
-\end{array}$ \\
\hline
\end{tabular}

(A) RCBT - Reactor CooTant BTeed Tank

(B) This table was excerpted from Reference 5 of REA Report [4].

(C) Preliminary results, as of November $25,1980$. 
TABLE 11. CALCULATED CURIE DEPOSITION IN PF-29 (GPU Reference 6) (5/9/80)

\begin{tabular}{|c|c|c|c|c|c|}
\hline \multirow{2}{*}{$\begin{array}{c}(n) \\
\text { Isotope }\end{array}$} & \multirow{2}{*}{$\begin{array}{c}(x) \\
\text { Cattion Deposition (C1) }\end{array}$} & \multirow{2}{*}{$\begin{array}{l}\quad(y) \\
\text { Activity } \\
\text { In Chemically } \\
\text { Bound Water (C1) }\end{array}$} & \multirow{2}{*}{$\begin{array}{l}(X+Y) \\
\text { Total }(C 4) \\
\end{array}$} & \multicolumn{2}{|c|}{$\begin{aligned} &(n / n-C s-137) \\
&\left.\text { Relative Isotopic Proportion (to } \mathrm{Cs}^{137}\right)\end{aligned}$} \\
\hline & & & & REA $A^{* \star}$ & $\underline{G P U \star * \star}$ \\
\hline Co-58 & $5.84 E-4$ & 7.12 E-6 & $5.91 \times 10^{-4}$ & $1.584 \times 10^{-6}$ & $6.805 \times 10^{-7}$ \\
\hline Co-60 & $2.05 E-3$ & $1.68 E-5$ & $2.067 \times 10^{-3}$ & $3.732 \times 10^{-6}$ & $2.380 \times 10^{-6}$ \\
\hline$S r-89$ & $1.49 E+1$ & $7.77 \mathrm{E}-2$ & $1.498 \times 10^{-1}$ & $4.843 \times 10^{-3}$ & $1.730 \times 10^{-2}$ \\
\hline$S r-90$ & $4.88 E+1$ & $2.56 \mathrm{E}-1$ & $4.906 \times 10^{-1}$ & $1.140 \times 10^{-2}$ & $5.650 \times 10^{-2}$ \\
\hline$y-90$ & $4.88 E+1$ & $2.56 E-1$ & $4.906 \times 10^{-1}$ & $1.140 \times 10^{-2}$ & $5.650 \times 10^{-2}$ \\
\hline$M n-54$ & $6.70 \mathrm{E}-3$ & $4.08 E-5$ & $6.14 \times 10^{-3}$ & $9.088 \times 10^{-6}$ & $7.761 \times 10^{-6}$ \\
\hline $2 r-95$ & $3.14 \mathrm{E}-2$ & $1.87 \mathrm{E}-4$ & $3.159 \times 10^{-2}$ & $4.160 \times 10^{-5}$ & $3.637 \times 10^{-5}$ \\
\hline Nb-95 & $6.31 \mathrm{E}-2$ & $3.71 E-4$ & $6.347 \times 10^{-2}$ & $8.262 \times 10^{-5}$ & $7.308 \times 10^{-5}$ \\
\hline Ru-i03 & $3.71 E-4$ & 8.74 E-6 & $3.797 \times 10^{-4}$ & $1.946 \times 10^{-6}$ & $4.372 \times 10^{-7}$ \\
\hline Rh-103m* & $3.71 \mathrm{E}-4$ & $8.74 E-6$ & $3.797 \times 10^{-4}$ & $1.945 \times 10^{-6}$ & $5.888 \times 10^{-7}$ \\
\hline Ru- 106 & $4.91 E-3$ & $2.02 \mathrm{E}-4$ & $5.112 \times 10^{-3}$ & $4.501 \times 10^{-5}$ & $5.886 \times 10^{-6}$ \\
\hline$R n-106$ & $4.91 \mathrm{E}-3$ & $2.02 E-4$ & $5.112 \times 10^{-3}$ & $4.501 \times 10^{-5}$ & $5.886 \times 10^{-6}$ \\
\hline $\mathrm{Ag}=110 \mathrm{~m} *$ & 0 & $5.30 E-6$ & $5.3 \times 10^{-6}$ & $1.179 \times 10^{-6}$ & $6.103 \times 10^{-9}$ \\
\hline Sn-113 & 0 & $5.26 E-6$ & $5.26 \times 10^{-6}$ & $1.171 \times 10^{-6}$ & $6.05 \times 10^{-9}$ \\
\hline$\left[n-113 m^{*}\right.$ & 0 & $5.26 \mathrm{E}-6$ & $5.26 \times 10^{-6}$ & $1.171 \times 10^{-6}$ & $6.056 \times 10^{-9}$ \\
\hline$S b-125$ & $5.84 E-2$ & $6.53 \mathrm{E}-4$ & $5.905 \times 10^{-2}$ & $1.453 \times 10^{-4}$ & $6.799 \times 10^{-5}$ \\
\hline Te-125m* & $1.34 \mathrm{E}-2$ & $1.50 \mathrm{E}-4$ & $1.355 \times 10^{-2}$ & ....- & $1.560 \times 10^{-5}$ \\
\hline$C 5-134$ & $1.91 E+2$ & $9.97 \mathrm{E}-1$ & $1.92 \times 10^{-2}$ & $1.880 \times 10^{-1}$ & $2.200 \times 10^{-1}$ \\
\hline Cs-137 & $8.64 E+2$ & 4.49 EO & $8.684 \times 10^{2}$ & 1.000 & 1.000 \\
\hline $8 a-137 m^{*}$ & $8.16 E+2$ & 4.26 EO & $8.202 \times 10^{2}$ & $9.499 \times 10^{-1}$ & $9.450 \times 10^{-1}$ \\
\hline$(e-14)$ & $1.31 E-4$ & $1.25 E-6$ & $1.323 \times 10^{-4}$ & $2.786 \times 10^{-7}$ & $1.523 \times 10^{-7}$ \\
\hline $\mathrm{Ce}-144$ & $4.64 \mathrm{E}-2$ & $4.45 E-4$ & $4.685 \times 10^{-2}$ & $9.915 \times 10^{-5}$ & $5.394 \times 10^{-5}$ \\
\hline \multirow[t]{2}{*}{ Pr-144 } & $4.64 \mathrm{E}-2$ & $4.45 \mathrm{E}-4$ & $4.685 \times 10^{-2}$ & $9.915 \times 10^{-5}$ & $5.394 \times 10^{-5}$ \\
\hline & & Total & \multicolumn{3}{|c|}{$\begin{array}{l}1994 \mathrm{Cf} \text { including all daughter products* } \\
1178 \mathrm{Cf} \text { excluding metastable daughter product s* }\end{array}$} \\
\hline
\end{tabular}

- Hote: International Comission on Radiation Units and Measurements Report, ICRU REPORT 19, July 1, 1971 specifically defines an isomeric transition as a nuclear transformation and is measured in units of curies. (should not be counted in sumation of total curles)

* Based upon $35.1 \mathrm{\mu Cl} / \mathrm{ml}$ (Cs-137) calculated activity for Sample 3 from Table I (auxfliary butlding water) **Based upon 868.49 C1 (Cs-137) total activity in preftiter no. 29 liner [6].

REA - Ridihalgh. Eggers \& Associates (Reference 4)

GPU - General Public Utilities (Reference 6) 


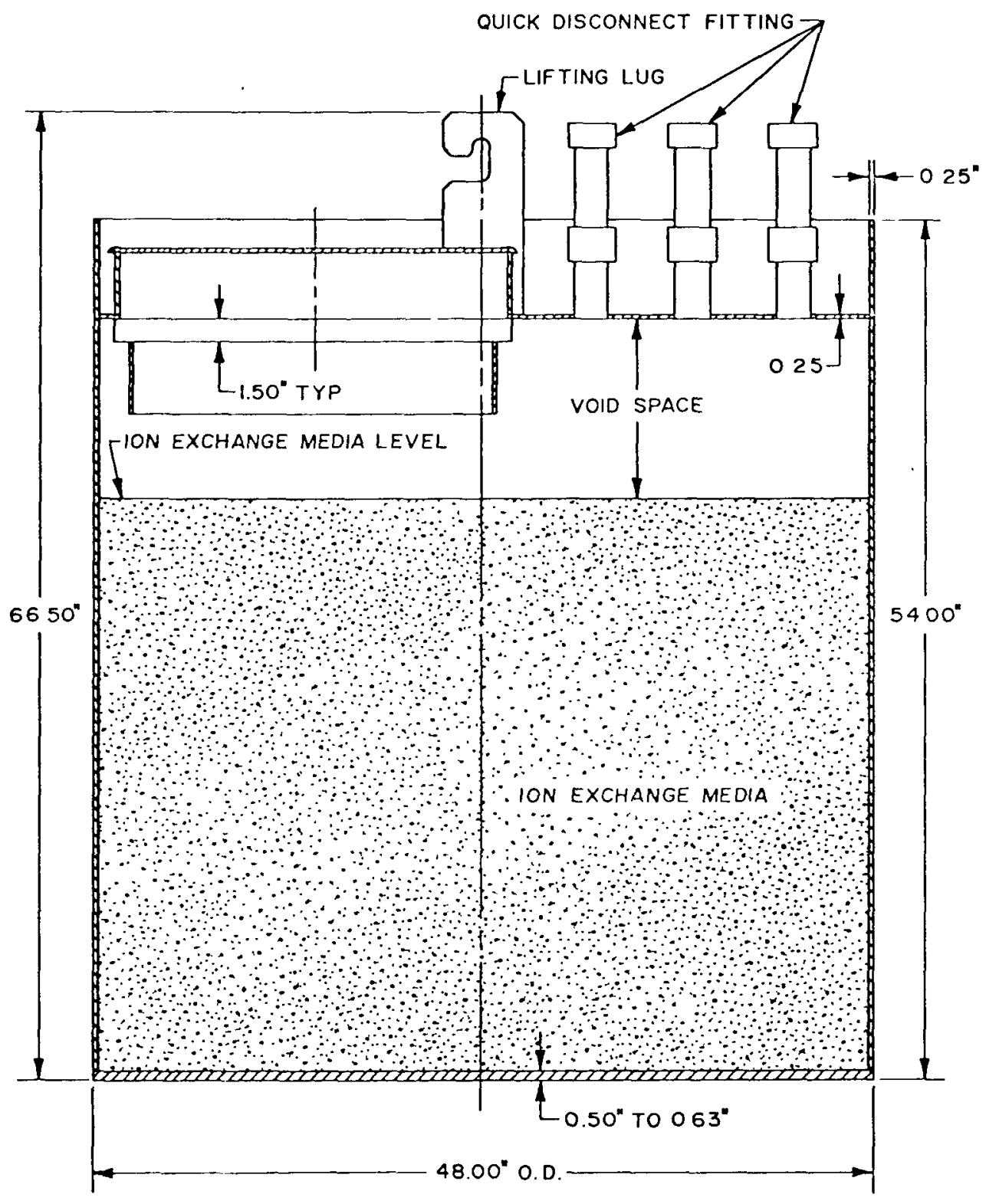

FIGURE 1. EPICOR II $4 \mathrm{FT} . X$ 4FT. LINER 


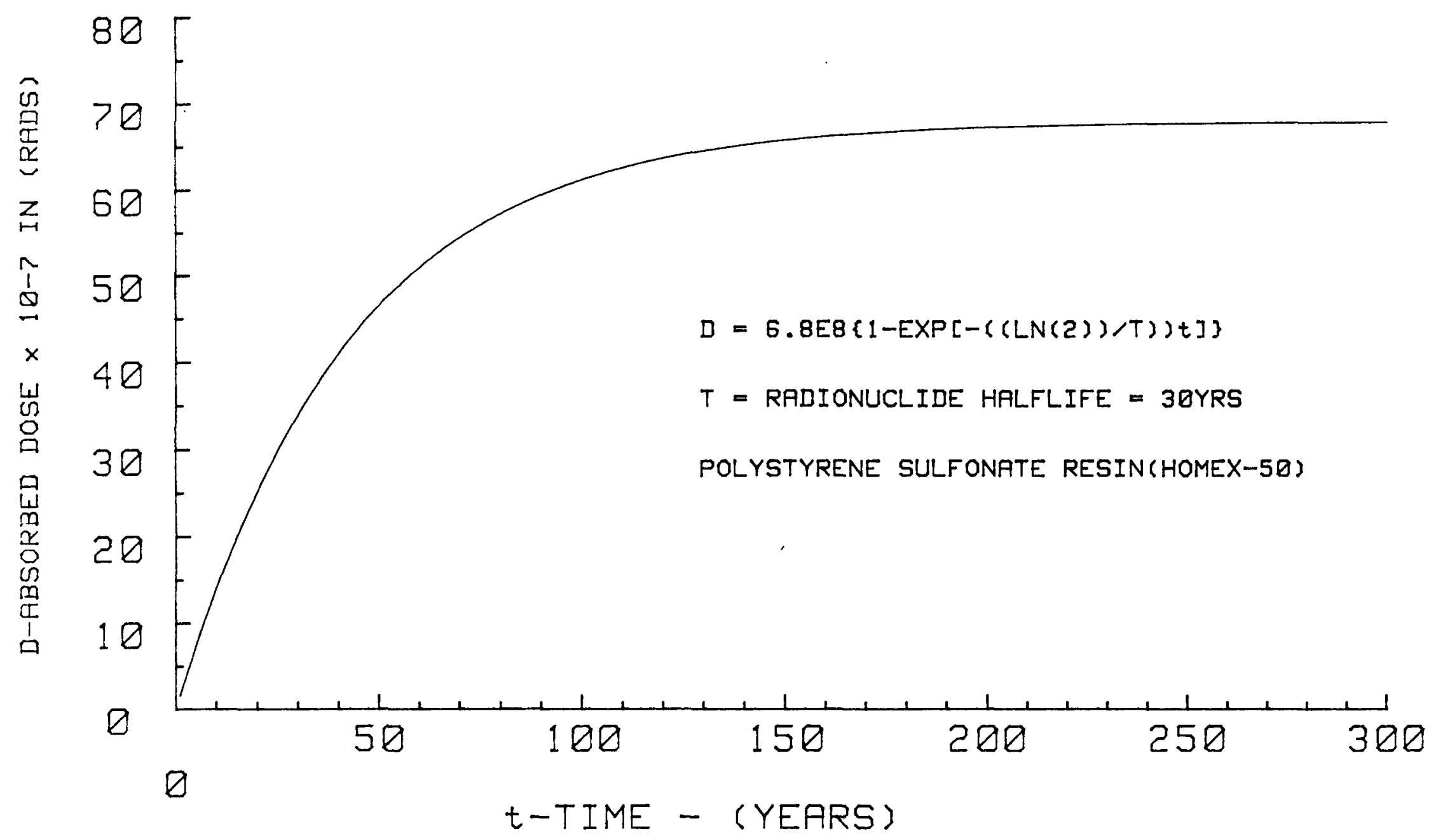

FIGURE 2. ABSORBED DOSE VERSUS LIFETIME FOR A 4FT. DIA. $x$ 4FT. LONG RESIN WASTE CONTAINER ( $1200 \mathrm{CI}, \mathrm{Cs} 137$ ) 


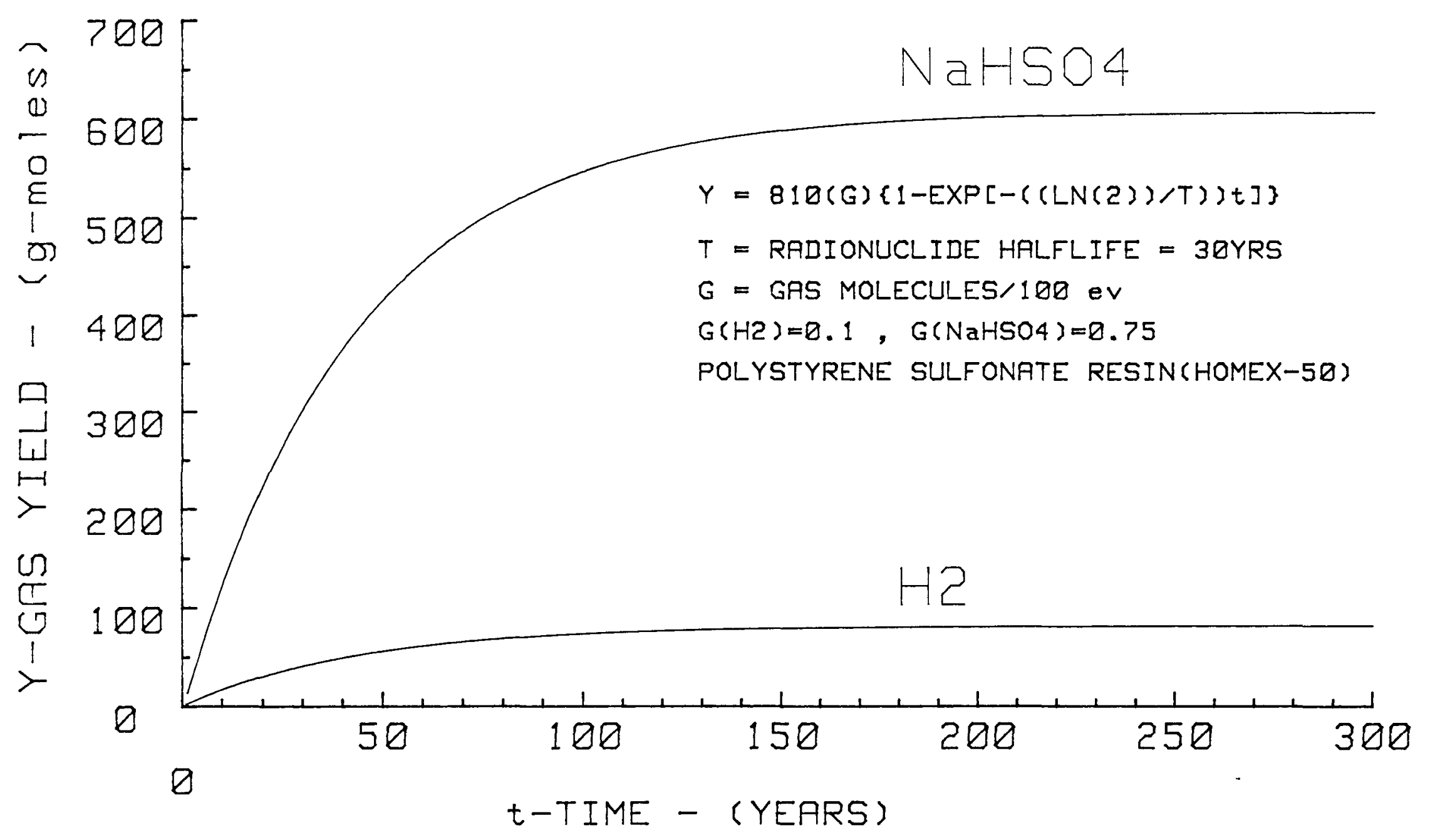

FIGURE 3. GENERATED GAS YIELD VERSUS LIFETIME FOR $A$ 4FT. DIA. X 4FT. LONG RESIN WASTE CONTAINER(1200CI, Cs 137) 


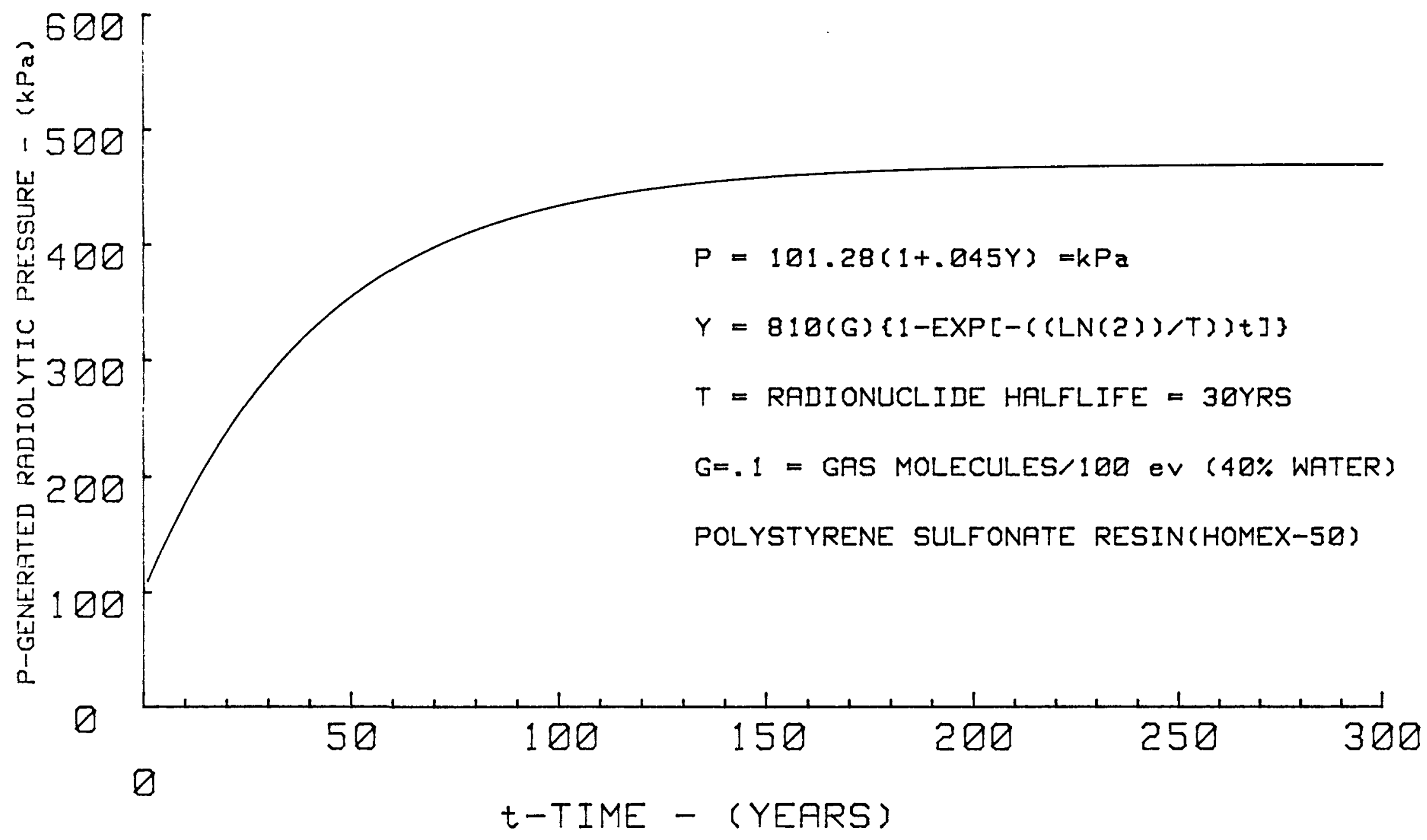

FIGURE 4. GENERATED RADIOLYTIC PRESSURE VERSUS LIFETIME FOR A 4FT. DIA. X 4FT. LONG RESIN WASTE CONTAINER( $1200 C I, C S 137)$ 


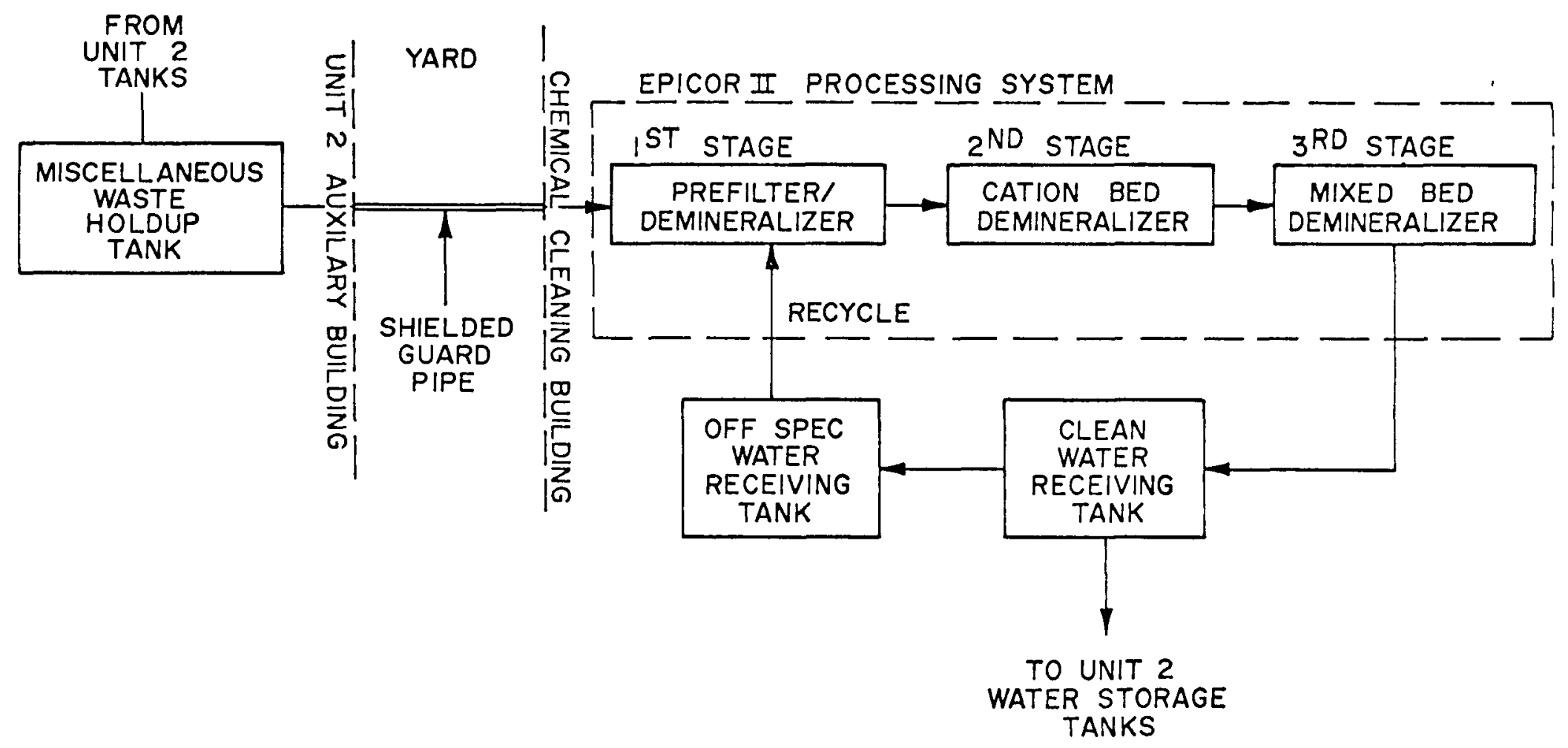

FIGURE 5. SCHEMATIC REPRESENTATION OF EPICOR II PROCESSING SYSTEM AT THREE MILE ISLAND 


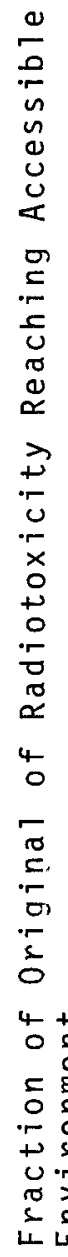

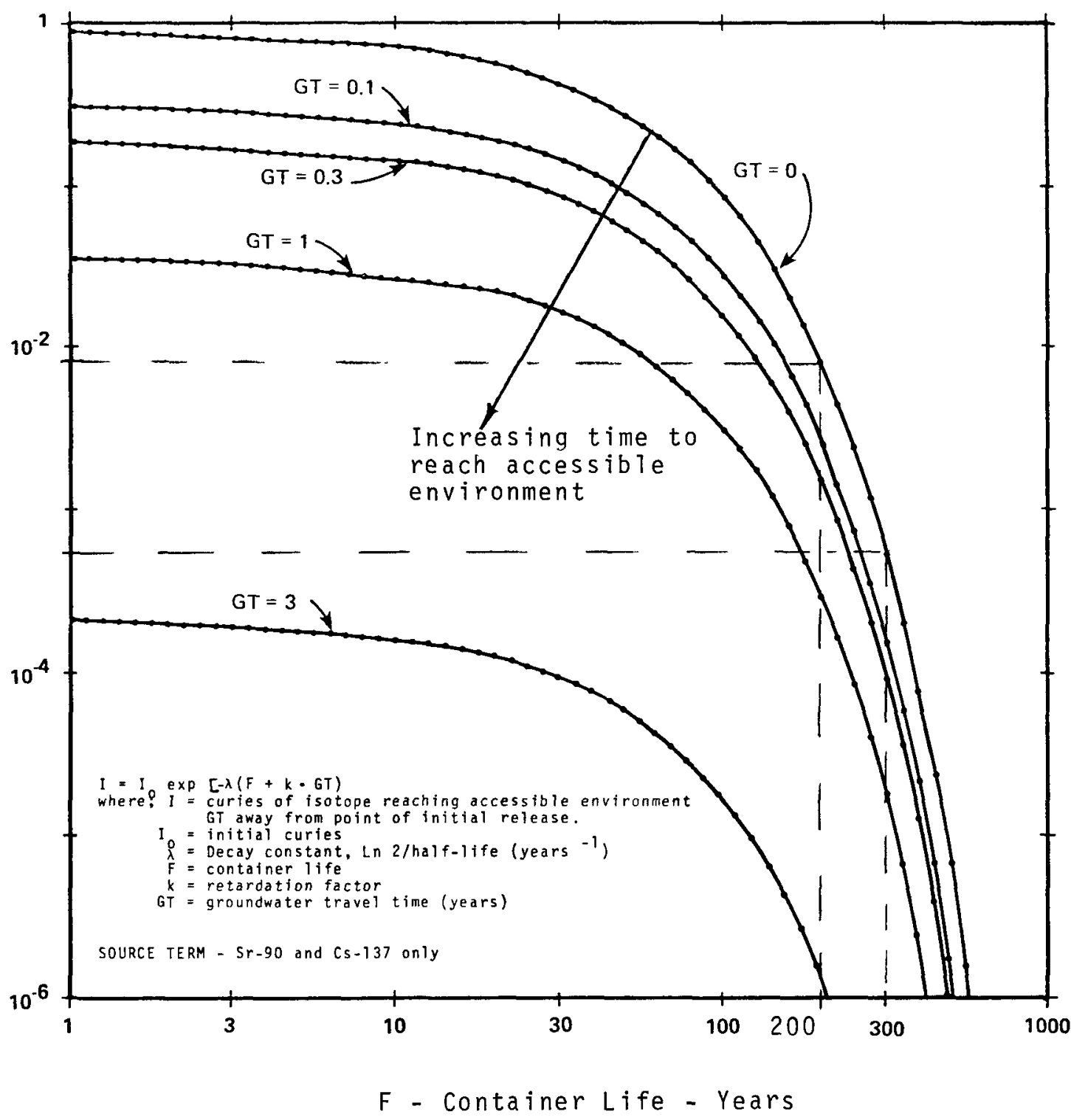

Figure 6. Fraction of the original radiotoxicity reaching the accessible environment as a function of container 1 ife $(F)$ and groundwater travel time (GT). 


\section{APPENDIX A}

1. SNL/TTC HIC Design Requirements after DOE/HQ Meeting in July 1980

2. NRC Draft High Integrity Container Design Guidelines (January 15, 1981)

3. High Integrity Container Design Guidelines (February 25, 1981)

4. South Carolina Department of Health and Environmental Control, "Staff Position on General Criteria for High Integrity Containers" 
This page intentionally left blank.

A-2 
SNL/TTC HIC Design Requirements after DOE/HQ Meeting, July 1980

(1) Provide zero release containment of radionuclides for 300 years.

(2) Provide structural integrity for 300 years.

(3) Fabrication costs of disposal system not to exceed $\$ 15,000$ per unit. $(\$ 20,000 /$ unit if overpack qualifies as Type B transportation container)

(4) Contain all internally generated gases.

(5) Withstand the $1 i$ thostatic pressure for a 50 foot burial depth.

(6) Must not float.

(7) Consider typical disposal sites, both wet only and dry only.

(8) Must be easily handled.

(9) Intruder protection will be provided by the disposal site.

(10) Internally (waste interaction) and externally (disposal site environment) corrosion resistant.

(11) Initially assume resin pH of about 2, possibly sulphurous.

(12) Installation of HIC

a) Ship in Type B package, install disposable HIC (DOP) at disposal site (DS).

b) Install disposable HIC at reactor site (RS), ship in Type B package to DS.

c) Install combined DOP/Type B at RS, dispose of DOP/Type B at DS.

(13) Design 12c to meet the requirements of 10CFR71 for transportation.*

(14) Design must address ALARA (As Low As Reasonably Achievable) in all phases.

(15) External resin liner dimensions are about $4 \mathrm{ft}$ in dia. by $5 \mathrm{ft}$ long and $6 \mathrm{ft}$ in dia. by $7 \mathrm{ft}$ long. (Required internal dimensions of HIC)

(16) Provide cost benefit study trade-offs $(500$ year overpack cost versus 300,200 , 100 year overpack).

* Safety Analys is Report (SAR) will not be prepared and Certificate of Compliance (COC) not to be applied for as part of this program 
NRC High Integrity Container Design Guidelines (January 15, 1981)

Scope

This guide is applicable to a high integrity container to be used for the disposal of nuclear power plant dewatered resins containing between $1 \mathrm{c} / \mathrm{cc}$ and $350 \mathrm{c} / \mathrm{cc}$ of nuclides with half-lives greater than 5 years. The resins are assumed to be dewatered to meet the disposal site requirements for no free standing liquids $10.5 \%$ of container volume or 1 gallon, whichever is less, of liquids with a moderate $\mathrm{pH})$.

\section{Requirements}

A. The container should maintain its physical integrity for 10 half-lives of the longest lived significant isotope. For routine resin wastes the isotopes of primary concern are Cs-137 and Sr-90 having 30-year half-lives. Therefore, the design lifetime of a container for routine resin wastes should be a minimum of 300 years.

B. As a minimum the following should be evaluated in assessing the integrity of the container over the 300-year design lifetime:

1. corrosion of the container under storage and burial site conditions;

2. corrosion of the container due to the contents;

3. mechanical strength of the container to withstand a load placed directly on the top surface of the container equivalent to 50 feet of material having a density of $150 \mathrm{lb} / \mathrm{cf}$;

4. mechanical strength to withstand routing loads from disposal site operations, such as trench compaction operations;

5. thermal loads from processing, storage, transportation, and burial;

6. radiation stability of the container material and the contents to inciude effects produced by irradiatin of the resins to include gas generation and acid formation.

C. The container should be able to meet the requirements for a Type A package as defined in 49 CFR 173.398(b). The free drop test may be performed in accordance with 10 CFR 71 Appendix A.

D. The container and the associated lifting devices should be able to withstand the forces applied during lifting operations. This includes adding a safety factor to cover "abrupt lifting." As a minimum, the container should be able to withstand a 3 g vertical load.

E. The container should avoid the collection or retention of water.

F. The container should remain sealed for the design lifetime of the container. 
February 25, 1981

\section{HIGH INTEGRITY CONTAINER DESIGN GUIDELINES}

(Distributed by Tim Johnson at HIC Design Requirements

Peer Review Meeting, March 11, 1981)

Scope:

This guide is applicable to a high integrity container to be used for the disposal of nuclear power plant dewatered resins containing up to $350 \mathrm{uc} / \mathrm{cc}$ of nuclides with halflives greater than 5 years. The resins are assumed to be dewatered to the extent that the remaining drainable liquid upon receipt at the disposal site would not exceed 0.5 percent of container volume or 1 gallon, whichever is less, and has a pH within the range of 4 to 11 .

Guidel ines:

A. The container should maintain its physical integrity for 10 half-lives of the longest lived significant isotope. For routine resin wastes the isotopes of primary concern are Cs-137 and Sr-90 having 30-year half-1ives. Therfore, the design 1 ifetime of a container for routine resin wastes should be a minimum of 300 years. For wastes containing isotopes having half-lives less than 30 years, containers may be designed with 1 ifetimes less than 300 years.

B. As a minimum the following should be evaluated in assessing the integrity of the container over the design lifetime:

1. corrosion of the container under storage and burial site conditions;

2. corrosion of the container due to the contents;

3. mechanical strength of the container to withstand a load placed directly on the top surface of the container equivalent to 35 feet of material having a density of $120 \mathrm{lb} / \mathrm{of}$;

4. mechanical strength to withstand routine loads from disposal site operations, such as trench compaction operations;

5. thermal loads from processing, storage, transportation, and burial;

6. radiation stability of the container material and the contents to include effects produced by irradiation of the resins, including gas generation and acid formation.

7. biodegradability of the container and contents under storage and burial site conditions.

C. The container should be able to meet the requirements for a Type A package as defined in 49 CFR 173.398(b). The free drop test may be performed in accordance wi th 10 CFR 71 Appendix A.

D. The container and the associated lifting devices should be able to withstand the forces applied during lifting operations. This includes adding a safety factor to cover "abrupt lifting." As a minimum, the container should be able to withstand a $3 g$ vertical load.

E. The container design should avoid the collection or retention of water on container surfaces.

F. The container should remain sealed for the design 1 ifetime of the container. Special vent designs which do not cause radionuclide migration over the design lifetime of the container may be considered if needed to relieve excessive internal pressures. 
RETYPED FOR LEGIBILITY

October 22, 1980

MEMORANDUM

TO: $\quad$ Heyward G. Shealy, Chief

Bureau of Radiological Health

FROM: Division of Rad. Material Licensing \& Compliance

Bureau of Radiological Heal th

SUBJECT: Staff Position on General Criteria for High Integrity Containers

In October 1979, the low-level waste facility license was, again, amended in its entirety. This revision to the burial license specifically defined our requirements for free standing liquids and set goals for their implementation. Al so discussed were the Department's goals to enhance the stability of the high concentration waste forms buried at the South Carolina site. One method to increase stability and containment of these waste forms is to require complete solidification. Another option is to improve the integrity of the burial containers.

High integrity containers could be a viable option to increase stability and long term containment of high concentration waste forms. High concentration waste forms are defined as ion exchange resins, filter media and other media used to concentrate and remove activation and corrosion products from plant process systems having specific activity of one (1) microcurie/cubic centimeter or greater of all radionuclides with greater than five (5) year half-lives. The high integrity containers for these waste forms should be designed and constructed to minimize any impact on the industry but also to meet the criteria established below. These containers should be designed to be used in conjunction with existing Type $A$ and Type $B$ specification shipping containers to meet the U. S. Department of Transportation requirements.

The general criteria for high integrity containers to be used for high concentration waste forms is as follows:

(1) The container must be capable of maintaining its contents until the radionuclides have decayed, approximately 300 years since two of the major isotopes of concern in this respect are Strontium 90 and Cesium 137 with half-lives of 28 and 30 years, respectively.

(2) The structural characteristics of the container with its contents must be adequate to withstand all the pressure and stresses it will encounter during all handling, lifting, loading, offloading, backfilling, and burial.

(3) The container must not be susceptible to chemical, galvanic or other reactions from its contents or from the burial environment.

(4) The container must not deteriorate when subjected to the elevated temperatures of the waste streams themselves, from processing materials inside the container, or during storage, transportation and burial. 
Memorandum

Page two

October 22, 1980

(5) The container must not be degraded or its characteristics deminished by radiation emitted from its contents, the burial trench or the sun during storage.

(6) All lids, caps, fittings and closures must be of equivalentmaterials and construction to meet all of the above requirements and must be completely sealed to prevent any loss of the container contents.

WBH :kn 
This page intentionally left blank. 


\section{APPENDIX B}

Terminology and Assumed Definitions 
This page intentionally left blank. 
Terminology and Assumed Definitions

Definitions for certain terms used in this report do not have generally accepted meanings, while other terms may be used in a special context. The following definitions and discussions are provided for the sake of clarity.

\section{Accessible Environment}

The point of interest or the environment of concern.

Aquifer

A water-bearing formation below the surface of the earth; the source of wells. A confined aquifer is overlain by relatively impermeable rock. An unconfined aquifer is one associated with the water table.

\section{Biosphere}

The part of the earth in which life exists, including the lithosphere, hydrosphere, and atmosphere.

\section{Containment} package.

Confining radioactive wastes within prescribed boundaries, e.g., within a waste

Curie (Ci) second.

That quantity of radionuclides which undergoes $3.7 \times 10^{10}$ disintegrations per

\section{Criterion}

A criterion is a qualitative test of whether a goal has been met. For example, if the goal is to protect the public health and safety, a criterion could be: No member of the public shall be exposed to radiation at levels for which adverse effects are anticipated.

\section{Dewatered Resin}

Organic and/or inorganic Resin waste that has the free standing water pumped out, typically leaving up to $0.15 \%$ of total container volume of free standing water. (1.63 gallons for $6 \mathrm{ft}$ dia $\times 6 \mathrm{ft}$ long liner) 


\section{Dispersion}

The spread of materials within soils from other than the bulk movement resulting from groundwater flow.

\section{Disposal}

Disposal of waste is putting it aside without any intent of further disposition (e.g., final emplacement of the wastes into intermediate depth burial or other disposal facilities, isolating radionuclides from the biosphere, accessible environment).

\section{Disposal Package}

The disposal package includes the actual waste, the waste form (i.e., the material used as a medium for the waste, such as concrete), the container for the waste/ waste-form (e.g., drum or box), and any overpacks (e.g., radiological shielding) which are disposed of with the waste.

\section{Dry Sites}

Arid disposal sites are those sites where the percolation of the rain is limited to the near surface. (Over the time frames of interest it may be possible for an arid site to change to a humid sitel. Arid sites are usually associated with aridclimates. It is possible that rare meteorological events at an arid site will cause brief periods of percolation to an aquifer.

\section{EPICOR II System}

The TMI-2 auxiliary building water decontamination system developed by EPICOR, Inc. and shown in Figure 5 taken from Reference 4 . This system was required to clean radioactive waste water with activity ranging from 1 to $100 \mathrm{Ci} / \mathrm{CC}$ [7]. Filtration and ion exchange resins are used in the process.

\section{Free Liquid}

Liquid that is free standing or not sorbed into a host material (resin) such that it could spill or drain from the container.

\section{Ground Water}

Water that exists or flows in or between geologic formations.

\section{Groundwater Travel Time (GT)}

The distance from the source term to the accessible environment divided by the groundwater velocity (hydrologic flowpath).

$\underline{\text { Half-Life }}$ element.

The time required for the disintegration of half the atoms of some specific radioactive 
HIC Life

The period from the time the waste form is emplaced inside the HIC to the time the HIC integrity is lost and wastes are free to escape (if liquid) from the container or to be leached from the waste form (if solid).

High Integrity Container (HIC)

A container or overpack for storing, transporting, and disposing of HSALL wastes. A container which increases the margin of protection of the public or environment from the waste form. Figures 1 and 2 illustrate a potential concept for a multilayered HIC. A second canister in the waste package, it provides a radionuclide release barrier. It provides additional corrosional or structural/resistance or additional radiation shielding for the waste form.

High-Specify Activity Low Level Waste (HSALL)

Waste defined as ion exchange resins, filter media, and other media used to concentrate and remove activation and corrosive products from plant process systems having activities and characteristics similar to those produced by the EPICOR II System at TMI-2. The resin wastes are also similar to dewatered resins used in processing cesium and strontium carrying liquids from DOE and commericial reactor and spent fuel operations. The wastes include solids, liquids and gases generated during the immobilization processes.

Immobilized Material

Materials that are fixed in a matrix such as glass, ceramic, cermet, concrete, resin, or other media.

Intermediate Depth Burial (IDB)

The disposal site burial depths required for disposal of HSALL wastes. HSALL waste has activity levels higher than normally considered acceptable for disposal by shallow land burial (up to a $3 \mathrm{~m}$ depth). Based on the July 1980 meeting at DOE/HQ, 10CFR61, and other references cited in the FBDU report [5], a minimum IDB of 15 meters (50 feet) was selected and a maximum of 30 meters (100 feet) was defined.

Ion exchange

A phenomenon in which chemical species in one phase of material exchange with similar species in another phase.

\section{Isotope}

One of two or more atoms with the same atomic numbers (the same chemical element) but with different physical properties.

Low Level Radioactive Waste (LLW)

Radioactive waste that is not defined by regulation to be high level radioactive waste $(H L W)$. HLW, as defined by NRC, includes spent fuel and aqueous wastes resulting from the operation of the first cycle solvent extraction system, or equivalent, and the concentrated wastes from subsequent extraction cycles, or equivalent, in a facility 
for the reprocessing of irradiated reactor fuels. The primary radionuclide of concern with these TMI wastes is Cesium 137 and 10CFR Part 61 (3) shows an upper limit of $1.3 \mathrm{Ci} / \mathrm{m}^{3}(1.3 \mu \mathrm{Ci} / \mathrm{cc})$ for shallow land burial (3 meter depth).

\section{Microbial Gas Generation}

Production and transformation of gases in ion exchange media by micro-organism or bacterial action.

Nuclide

A general term applicable to all atomic forms of the elements; nuclides comprise all the isotopic forms of all the elements. Nuclides are distinguished by their atomic number, atomic mass, and energy state.

\section{Radiation dose}

Amount of radiation received by individuals or a population, expressed in units of rem or mrem (1/1000 of a rem). Background radiation from natural sources is approximately $200 \mathrm{mrem} / \mathrm{year}$ to an average individual in the U.S.

\section{Radioactivity}

The spontaneous decay of disintegration of an unstable atomic nucleus, usually accompanied by the emission of ionizing radiation.

\section{Radiolytic Gas Generation}

Generation of gas due to the effects of radiation on ion exchange media.

\section{Radionuclide}

A nuclide (species of atom distinguished by the constitution of its nucleus) that is unstable and is undergoing the process of spontaneously decaying to another nuclide.

\section{Retardation Factor}

Groundwater velocity divided by the velocity of a particular substance, or the relative movement of a particular substance radionuclide in groundwater.

\section{Sealed HIC}

An HIC that remains sealed for the designed lifetime of the container with the exception that gas release will be allowed not to exceed that which would occur if the resins were solidified.

\section{Storage}

Storage of waste is putting it aside for safekeeping, pending further disposition (e.g., the placement of the wastes into a warehouse or other facility prior to shipment for disposal.) 
Transuranic (TRU) Waste

Waste defined as waste contaminated with certain alpha emiting radionuclides of long half-life and have specific radiotoxicity to greater than 10 nanocuries per gram. The nuclides included are: $U^{233}$ (and its daughter products), Plutonium and transplutonium nuclides. Transuranic wastes (i.e., those wastes containing elements with atomic numbers greater than 92) which are not part of HLW will be considered to be LLW. Radioactive wastes do not include naturally occurring radioactive materials such as coal, phosphates or mine tailings.

\section{Waste Form}

The $4 \mathrm{ft}$ dia $X 4 \mathrm{ft}$ long EPICOR II liner and contents shown in Figure 1 is the waste form.

\section{Wet Sites}

Humid disposal sites are those sites where there is percolation of rainwater to an underlying aquifer. 


$$
\text { . }
$$

: 
DISTRIBUTION: Unlimited Release

U. S. Department of Energy (166)

Attn: DOE/TIC-4500-R68 UC71

Technical Information Center

Oak Ridge, TN 37830

American Nuclear Society

Attn: M. D. Weber

ANS STANDARDS

$555 \mathrm{~N}$. Kensington Avenue

La Grange Park, IL 60525

Atomic Industrial Forum (AIF)

Attn: D. Harwood

7101 Wisconsin Avenue NW

Washington, DC 20014

W. W. Bixby

Manager, DOE/TMI Site Office

P. 0 . Box 88

Middletown, PA 17057

Boston Edison Co.

Attn: G. J. Davis

800 Boylston St.

Boston, MA 02199

Brookhaven National Laboratory

Attn: Al Weiss

Division of Nuclear Waste Management

Building 83

Upton, NY 11973

Brookhaven National Laboratory

Attn: P. Columbo

As sociated Universities, Inc.

Bldg. 703

Upton, Long IsI and, NY 11973

Chemical Data Systems

Attn: K. E. Jackson

3620 N. High Street

Columbus, $\mathrm{OH} \quad 43214$

Chemical Nuclear Systems, Inc.

Attn: John Potter

P. 0. Box 1866

Bellevue, WA 98009

DOE Operations Office

Attn: R. Nel son

P. 0. Box 1625

Idaho Falls, ID 83415

E.E.I.

Attn: R. E. L. Standford

1111 North igth Street N.W.

Washington, D.C. 20036
EG\&G Idaho

Attn: R. L. Chapman

M. Krupinski

G. Levin

P. 0. Box 1625

Idaho Falls, Idaho 83415

EG\&G Technical Integration Office (10)

Attn: R. E. Holzworth

P. 0. Box 88

Middletown, PA 17057

EPICOR, Inc.

Attn: R. Hetherington

1375 E. Linden Ave.

Linden, NJ 07036

Ford, Bacon \& Davis, Utah

Attn: John Adam

375 Chipeta Way

Salt Lake City, UT 84108

K. A. Gablin

6749 Towne Lane Road

McLean, VA 22101

General Atomic Company

Attn: George Wes sman

P. 0. Box 81608

San Diego, CA 92138

General Public Utilities

Attn: D. R. Buchanan

Manager, Technical Planning

P. 0. Box 88

Middletown, PA 17057

IEAL

Attn: C. A. Negin

Suite 600

600 New Hampshire Ave., N.W.

Washington, DC 20037

Los Alamos Scientific Laboratory

Attn: M. Wheeler

Environmental Research Division

Los Alamos, NM 87545

Metropolitan Edison Co.

Attn: R. J. McGoey, G. Horey

P. O. Box 480

Middletown, PA 17057

Nuclear Regulatory Commission

Attn: L. Bell

7920 Norfolk Avenue, Rm. 532

Bethesda, MD 20014 
Nuclear Safety Assoc., Inc.

Attn: Walt Rodger

5101 River Road

Bethesda, MD 20014

Oak Ridge National Laboratories

Attn: H. W. Godbee, A. H. Kibbey,

P. 0. Box $X$

D. Large and P. Lotz

Oak Ridge, TN 37830

Ridihalgh, Eggers, and Associates, Inc.

Attn: John L. Ridihalgh, Philip E. Eggers, Elmer C. Lusk, John R. Genser, and James R. Myers

2219 Summit Street

Columbus, Ohio 43201

Savannah River Laboratory

Attn: R. M. Wallace

Aiken, SC 29808

Sheppard T. Powell Assoc.

Attn: J. W. Si egmund

31 Light Street

Baltimore, MD 21202

South Carolina Department of Heal th and Environmental Control

Attn: Virgil Autry, R. S. Jackson

Division of Rad. Material Licensing and Compliance

2600 Bull Street

Columbia, S.C. 29201

Stone \& Webster Corp.

Attn: P. Mayo

245 Summer St.

P. 0. Box 2325

Boston, MA 02107

Sybron Corporation

Attn: F. X. McGarvey

Chemical Division

Burlington, $\mathrm{NJ} 08011$

U. S. Department of Energy (2)

Attn: K. Carlson, Transportation Manager

R. Y. Lowrey, Chief Waste Material Branch

Albuquerque Operations office

Albuquerque, NM 87115

U. S. Department of Energy

Office of Waste Isolation

C. A. Heath, Director

Mail Stop B-107

Washington, DC 20545
U. S. Department of Energy (9)

Attn: T. Anderson

R. B. Chitwood

J. T. D'Ambrosia

F. P. Falci

H. Feinroth

M. J. Lawrence

T. McIntosh

S. Meyers

J. A. Sisler

Washington, D.C. 20545

U. S. Ecology, Inc.

Attn: W. Hipsher

P. 0. Box 7246

9200 Shelbyville Road

Suite 526

Louisville, KY 40207

U. S. Nuclear Regulatory Commission (2)

Attn: Ken Jackson, Tim Johnson

Division of Waste Management

Mail Stop 905-55

Washington, DC 20555

Water Resources Center

Attn: R. French

Desert Research Institute

P. 0. Box 60220

Reno, Nevada 89506

Sandia National Laboratory

P. 0. Box 5800

A1buquerque, NM 87185

Attn: 4500 E. H. Beckner

Attn: 4510 W. D. Weart

4530 R. W. Lynch

4540 M. L. Kramm

4512

4512

4550

T. 0 . Hunter

M. A. Molecke

R. M. Jefferson

Attn: TTC Master File

4551

4551

4551

4551

4552

4552

4552

4553

4553

4553

4551

8214

3141

3151

R. E. Luna

E. W. Shepherd

J. D. McClure

E. L. Wilmot

R. B. Pope

L. E. Romesberg

A. A. Trujillo

G. C. Allen

M. G. Vigil (10)

H. R. Yoshimura

TTC Library (10) File 2002.060

M. A. Pound

L. J. Erickson (5)

W. L. Garner (3) 



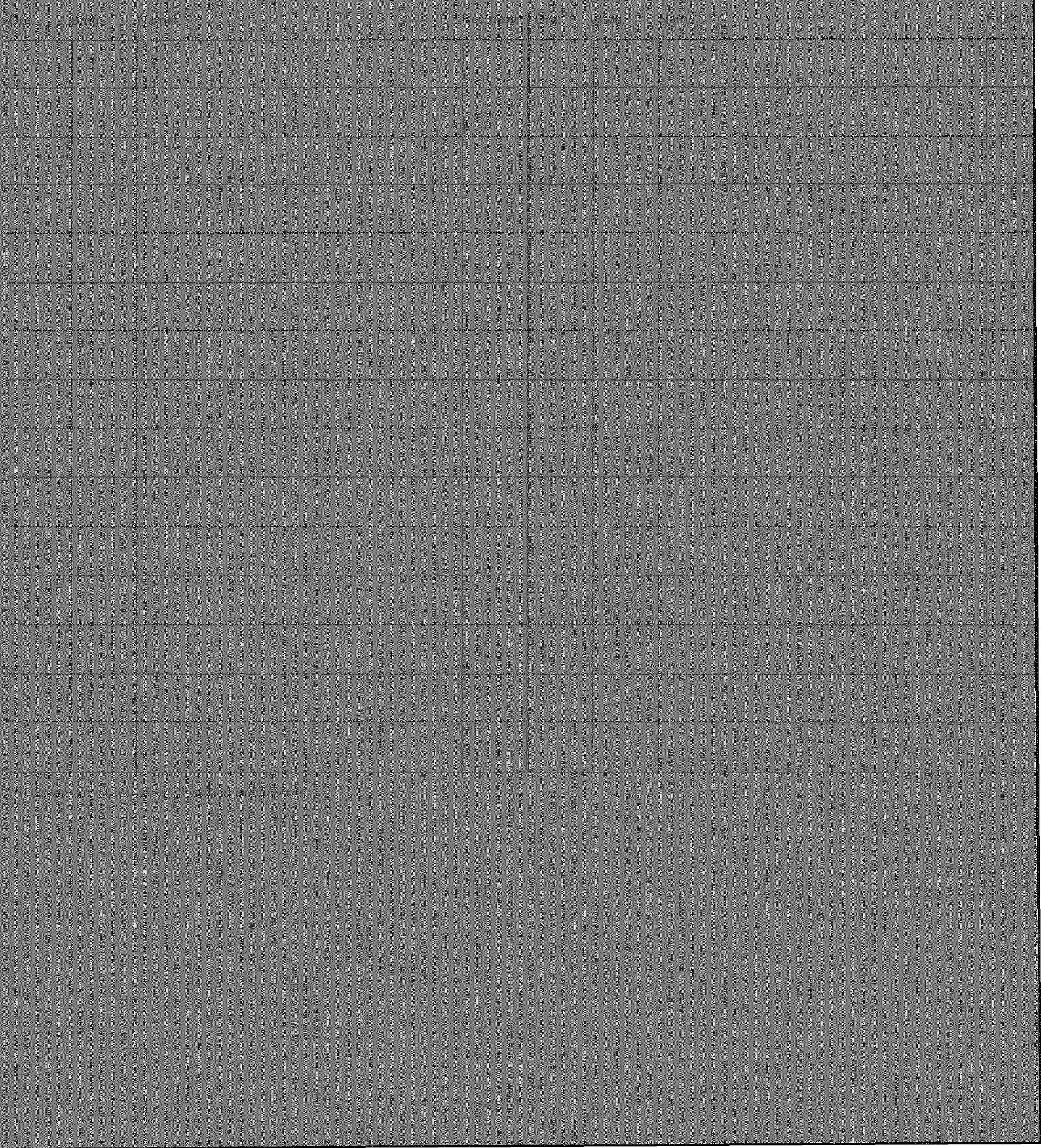

